Review

\title{
How closely do mercury trends in fish and other aquatic wildlife track those in the atmosphere? - Implications for evaluating the effectiveness of the Minamata Convention
}

\author{
Feiyue Wang $^{\mathrm{a}, *}$, Peter M. Outridge ${ }^{\mathrm{a}, \mathrm{b}}$, Xinbin Feng ${ }^{\mathrm{c}}$, Bo Meng ${ }^{\mathrm{c}}$, Lars-Eric Heimbürger-Boavida ${ }^{\mathrm{d}}$, \\ Robert P. Mason ${ }^{\mathrm{e}}$ \\ ${ }^{a}$ Center for Earth Observation Science, Department of Environment and Geography, University of Manitoba, Winnipeg, MB R3T 2N2, Canada

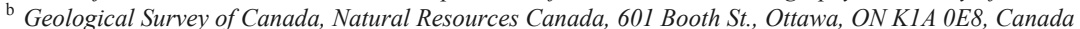 \\ c State Key Laboratory of Environmental Geochemistry, Institute of Geochemistry, Chinese Academy of Sciences, 46 Guanshui Road, Guiyang 550002, China \\ d Aix Marseille Université, CNRS/INSU, Université de Toulon, IRD, Mediterranean Institute of Oceanography (MIO) UM 110, 13288 Marseille, France \\ e Department of Marine Sciences, University of Connecticut, 1080 Shennecossett Road, Groton, CT 06340, USA
}

\section{A R T I C LE INFO}

Article history:

Received 17 February 2019

Received in revised form 7 April 2019

Accepted 8 April 2019

Available online $\mathrm{xxx}$

Editor: Mae Sexauer Gustin

Keywords:

Mercury

Aquatic ecosystems

Atmospheric emissions

Fish

Climate change

Minamata Convention

\begin{abstract}
A B S T R A C T
The Minamata Convention to reduce anthropogenic mercury (Hg) emissions entered into force in 2017, and attention is now on how to best monitor its effectiveness at reducing $\mathrm{Hg}$ exposure to humans. To address this, a key question is how closely $\mathrm{Hg}$ concentrations in the human food chain, especially in fish and other aquatic wildlife, will track the changes in atmospheric $\mathrm{Hg}$ that are expected to occur following anthropogenic emission reductions. We investigated this question by evaluating several regional groups of case studies where $\mathrm{Hg}$ concentrations in aquatic biota have been monitored continuously or intermittently for several decades. Our analysis shows that in most cases $\mathrm{Hg}$ time-trends in biota did not agree with concurrent $\mathrm{Hg}$ trends in atmospheric deposition or concentrations, and the divergence between the two trends has become more apparent over the past two decades. An over-arching general explanation for these results is that the impact of changing atmospheric inputs on biotic Hg is masked by two factors: 1) The aquatic environment also contains a large inventory of legacy emitted $\mathrm{Hg}$ that remains available for bio-uptake leading to a substantial lag in their response time to a change in external inputs; and 2) Biotic Hg trends reflect the dominant effects of changes in multi-causal, local and regional processes (e.g., aquatic or terrestrial biogeochemical processes, feeding ecology, climate) that control the speciation, bioavailability, and bio-uptake of both present-day and legacy emitted Hg. Globally climate change has become the most prevalent contributor to the divergence. A wide range of biotic $\mathrm{Hg}$ outcomes can thus be expected as anthropogenic atmospheric $\mathrm{Hg}$ emissions decline, depending on how these processes operate on specific regions and specific organisms. Therefore, evaluating the effectiveness of the Minamata Convention will require biomonitoring of multiple species that represent different trophic and ecological niches in multiple regions of the world.
\end{abstract}

(C) 2019 .

\section{Introduction}

The entry into force in August 2017 of the Minamata Convention on Mercury was an important step in international efforts to control mercury $(\mathrm{Hg})$ releases into the environment and to protect human health from its harmful effects (www.mercuryconvention.org). Subsequently, in accordance with Article 22 of the Convention, the Second Conference of the Parties (COP2) in November 2018 turned its attention in part to the question of how best to evaluate the effectiveness of the Convention in meeting its goals (www.mercuryconvention.org/ Meetings/Intersessionalnbsp;work/tabid/6325). Monitoring of biotic $\mathrm{Hg}$ concentrations and trends should logically be an important part of

\footnotetext{
* Corresponding author.

Email address: feiyue.wang@umanitoba.ca (F. Wang)
}

this evaluation, given the central role of aquatic food chains (fish and other aquatic wildlife) in defining human $\mathrm{Hg}$ exposure (Basu et al., 2018; Eagles-Smith et al., 2018; Gustin et al., 2016). However, a key question remains as to which extent measurements of $\mathrm{Hg}$ in aquatic biota will track the changes in atmospheric $\mathrm{Hg}$ that are expected to occur following future anthropogenic emission reductions.

The atmospheric and aquatic chemistry of $\mathrm{Hg}$ is one of the most complex of all trace metals. The $\mathrm{Hg}$ that is emitted from anthropogenic (and natural) sources to air is almost exclusively inorganic as elemental $\left(\mathrm{Hg}^{0}\right)$ and divalent compounds $\left(\mathrm{Hg}^{\mathrm{II}}\right)$ in gaseous and particulate forms (Obrist et al., 2018). Redox reactions between $\mathrm{Hg}^{0}$ and $\mathrm{Hg}^{\text {II }}$ in the atmosphere are primarily photochemically driven (Ariya et al., 2015; Saiz-Lopez et al., 2018), with the bulk of the atmospheric $\mathrm{Hg}$ deposited onto the Earth's surface (oceans, land, and freshwaters) being in the form of inorganic $\mathrm{Hg}^{\text {II }}$. The aquatic environment also receives $\mathrm{Hg}$ input, primarily as inorganic $\mathrm{Hg}^{\mathrm{II}}$, from rivers, 
catchment runoff, and submarine groundwater discharge (Fitzgerald and Lamborg, 2014; Outridge et al., 2018). Once in the aquatic environment, the net transformation of inorganic $\mathrm{Hg}^{\text {II }}$ through methylation to methylmercury $(\mathrm{MeHg})$ is the key step in the $\mathrm{Hg}$ cycle leading to wildlife and human exposure. Methylmercury is one of the most bioaccumulative and toxic $\mathrm{Hg}$ species and is the only form that is biomagnified through food chains (Eagles-Smith et al., 2018; Fitzgerald and Lamborg, 2014).

Therefore, the relationship between anthropogenic $\mathrm{Hg}$ emissions to the atmosphere and $\mathrm{Hg}$ trends in aquatic biota is influenced by many environmental and ecological factors (e.g., temperature, light intensity, $\mathrm{pH}$, redox condition, organic carbon and nutrient concentrations, and food web structure and dynamics) that control the rates of $\mathrm{Hg}$ deposition from the atmosphere, $\mathrm{MeHg}$ production (methylation) and degradation (demethylation) in the aquatic environment, and the uptake of $\mathrm{Hg}$, especially $\mathrm{MeHg}$, by biota (Eagles-Smith et al., 2018; Hsu-Kim et al., 2018). The complexity of these processes, along with the large inventories of legacy anthropogenic and natural $\mathrm{Hg}$ stored long-term in terrestrial and aquatic systems, suggests that biotic $\mathrm{Hg}$ may be only tenuously connected to atmospheric $\mathrm{Hg}$ which has a much shorter life-time ( 0.5 to 2 years) than the decadal or century-scale life-times of $\mathrm{Hg}$ in soils and oceans (Horowitz et al., 2017; Saiz-Lopez et al., 2018). Furthermore, even if atmospheric and biotic $\mathrm{Hg}$ do follow similar trends, there could be a significant time lag between their response. The response also likely differs in ecosystems of different sizes and complexity: changes in biotic $\mathrm{Hg}$ in marine ecosystems could lag significantly behind those in smaller, freshwater ecosystems (Sunderland and Mason, 2007; Sunderland and Selin, 2013).

One aspect of the United Nations Environment Programme (UNEP)'s Global Mercury Assessment (AMAP/UNEP, 2019) was a review of relationships between the trends of atmospheric $\mathrm{Hg}$ and $\mathrm{Hg}$ in fish and other aquatic wildlife, and the reasons for the match or mis-match between those trends. These relationships are important because of their relevance to predicting the efficacy of international regulatory actions, as prescribed in the Minamata Convention, in ultimately reducing $\mathrm{Hg}$ exposure in humans and wildlife. This review examines major case studies on biotic $\mathrm{Hg}$ trends in globally distinct regions, and compares them with concurrent atmospheric $\mathrm{Hg}$ trends in the same region, summarized in four regional groups of case studies. The studies are from North America, Europe, China, and the Arctic, where $\mathrm{Hg}$ concentrations in certain aquatic biota have been monitored continuously or intermittently for several decades. No such long-term time-series data for biotic $\mathrm{Hg}$ are available for other regions of the world, especially for the Southern Hemisphere. Our findings are then discussed in the context of monitoring the effectiveness of the Minamata Convention.

\section{Trends in atmospheric $\mathrm{Hg}$ concentration and wet deposition}

Before presenting the biotic $\mathrm{Hg}$ trend case studies, we first review the general trends in $\mathrm{Hg}$ concentrations in air and in wet deposition, with which the aquatic biotic $\mathrm{Hg}$ trends will be compared.

\subsection{North America and Europe}

North America and Europe are considered together here because their overall atmospheric $\mathrm{Hg}$ concentrations and deposition fluxes have trended similarly over the past few decades (Zhang et al., 2016). Measured $\mathrm{Hg}$ concentrations in the air (as gaseous elemental mercury (GEM), or total gaseous mercury (TGM)) declined by $10-40 \%$ between 1990 and 2010 throughout most of North America and Europe (Cole et al., 2014; Slemr et al., 2011; Weiss-Penzias et al., 2016), a pattern that has been matched by trends in $\mathrm{Hg}$ concentrations and fluxes in wet deposition (Brigham et al., 2014; Prestbo and Gay, 2009; Weiss-Penzias et al., 2016; Zhang and Jaeglé, 2013), as well as by lake sediment core records (e.g., Drevnick et al., 2016). This general declining trend agrees very well with the declining $\mathrm{Hg}$ point-source emissions in North America and Europe over the same period (AMAP, 2010; AMAP/UNEP, 2013), and has been reasonably well reproduced by a recent modelling study with revised global $\mathrm{Hg}$ emissions inventories (Fig. 1) (Zhang et al., 2016). This model study accounted for the declining emissions from commercial $\mathrm{Hg}$-containing products since 1990, corrected for shifts in the speciation of airborne $\mathrm{Hg}$ emissions related to air pollution control technology, and reduced the putative importance of atmospheric $\mathrm{Hg}$ emissions from artisanal and small-scale gold mining (ASGM).

However, a closer analysis of the observational data in Fig. 1 suggests that this systematic declining trend may have become less clear
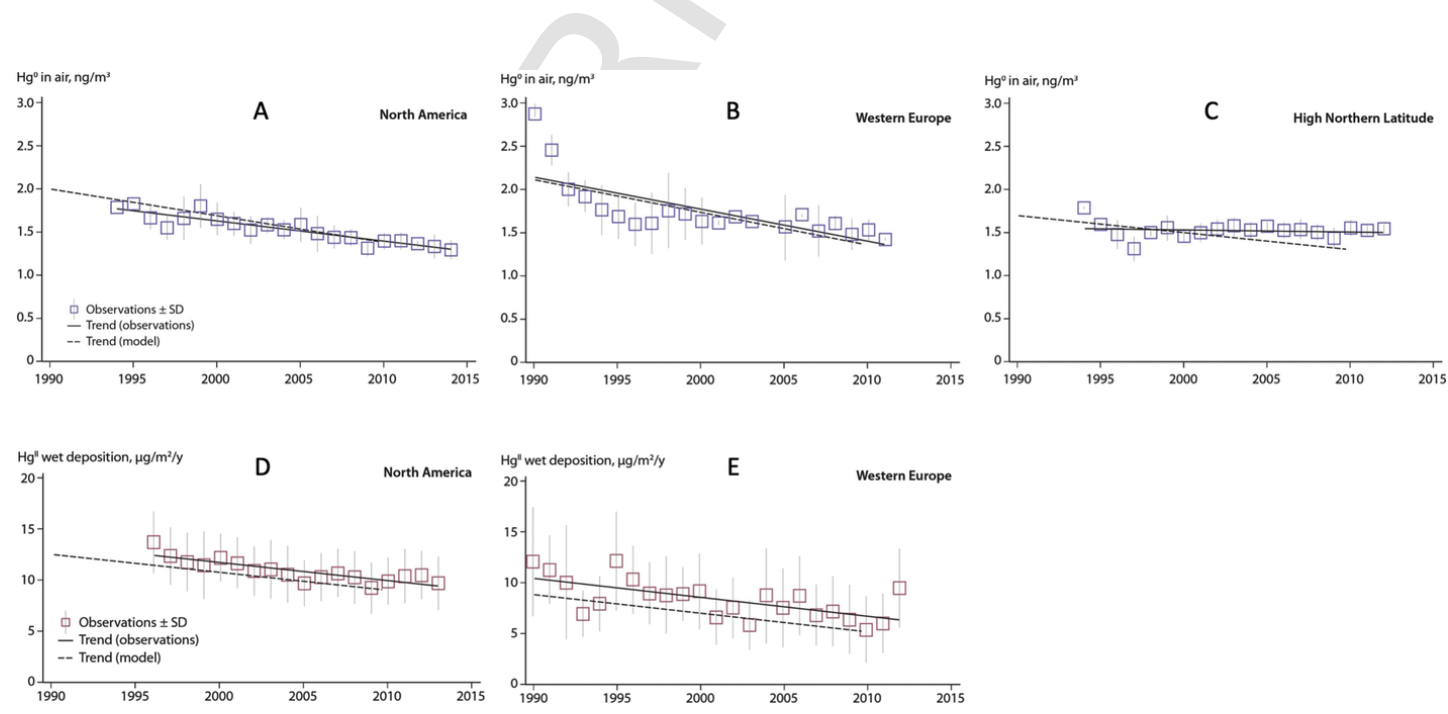

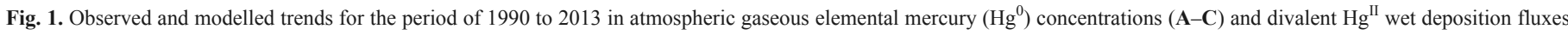

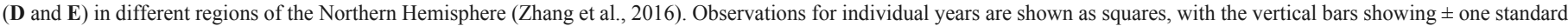

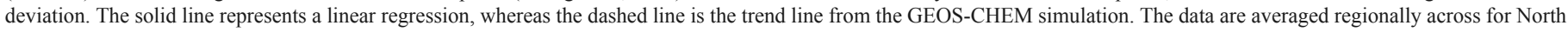
America (A and D), Western Europe (B and E), and high northern latitude regions (C). 
and uniform, and even reversed, over the most recent decade (i.e., since 2008). This is demonstrated by a recent study in North America (Weiss-Penzias et al., 2016) that showed gaseous elemental $\mathrm{Hg}$ concentrations in the air had stabilized since 2008 with a flat slope over time. While $\mathrm{Hg}$ concentrations and fluxes in wet deposition continued to decline in some regions (e.g., Risch and Kenski, 2018), an increasing trend has also been observed throughout North America (Weiss-Penzias et al., 2016). Such a divergency in the recent air Hg trend likely reflects varying local, regional and global influences, and is not reproduced by the model of Zhang et al. (2016) (see Fig. 1).

\subsection{China}

China is the largest national emitter of anthropogenic $\mathrm{Hg}$ to the atmosphere (Fu et al., 2015). In contrast to the global trend, anthropogenic $\mathrm{Hg}$ emissions in China increased rapidly from 1978 to around 2007 at an average rate of $\sim 5.5 \%$ per year, except for the period 1998-2000 when emissions decreased due to the Asian financial crisis that led to a reduction in fuel consumption (Wu et al., 2016). Mercury emissions in China are reported to have plateaued around 2007 to 2010, and have shown a declining trend in the past few years (Wu et al., 2016). Available but limited data on atmospheric Hg concentrations over the past decade in China generally agree with this emissions trend. Direct measurements of GEM at Guiyang, an urban site in southwest China, showed that annual mean GEM concentrations increased at a rate of $\sim 2.5 \%$ per year between 2002 and 2010 (Fu and Feng, 2015). GEM concentrations also increased at Mt. Changbai, a remote alpine site in northeastern China, at about the same rate from 2009 to 2013, but appear to have stabilized since (Fu et al., 2015; Fu et al., 2016). Mercury passive sampling and plant biomonitoring on the Tibetan Plateau suggest that atmospheric Hg concentrations were stable during 2006 to 2009 and decreased during 2010 to 2015 (Tong et al., 2016) that agrees with the $\mathrm{Hg}$ records in sediment and glacier ice cores from the Tibetan Plateau (Kang et al., 2016).

\subsection{The Arctic}

Long-term air $\mathrm{Hg}$ monitoring data are available at several Arctic sites (above $60^{\circ} \mathrm{N}$ ), such as Alert (Nunavut, Canada), Villum Research Station at Station Nord (Greenland), and Zeppelin Station (Svalbard, Norway). The results show that atmospheric $\mathrm{Hg}$ concentrations have been generally declining, but at a markedly slower rate than elsewhere (Cole et al., 2013, 2014). The observed and modelled trends also disagreed more than in other regions, with observed GEM concentrations decreasing by $\sim 0.2 \%$ per year since 1994 , compared to a modelled decrease of $1.3 \%$ per year (Fig. 1). Deposition of atmospheric mercury can occur in the form of oxidized mercury to the Arctic coastal and marine environment during the spring-time atmospheric mercury depletion events (Schroeder et al., 1998), and in the form of gaseous elemental mercury via tundra uptake in the interior Arctic (Obrist et al., 2017). Unfortunately, there are no decade-long observational data of $\mathrm{Hg}$ deposition flux available for the Arctic or subarctic regions; existing depositional data are limited to one to two years of measurements only (Sanei et al., 2010).

\section{Trends in Hg in aquatic biota and possible causes}

\subsection{Case study 1: fish and birds in lakes and coastal waters of North America}

A large number of studies have reported inconsistent, diverging, or mixed temporal trends of $\mathrm{Hg}$ in aquatic biota throughout North America. The Great Lakes are an especially interesting study area because of the wide diversity of species monitored within the same general area, and the length of some of the biotic time trend datasets. Also, there is $\mathrm{Hg}$ isotopic evidence from two predatory Great Lakes fish (lake trout Salvelinus namaycush and burbot Lota lota) that established that the atmosphere, rather than sediments or watershed soils, was the ultimate source of most of the $\mathrm{Hg}$ accumulated into fish tissues in these large ecosystems (Lepak et al., 2015). This is consistent with earlier mass balance studies (Mason and Sullivan, 1997). However, intervening ecological, geochemical or climatic processes may be acting to drive biological time trends along divergent paths. Blukacz-Richards et al. (2017) evaluated the temporal trends since the 1970s of $\mathrm{Hg}$ concentrations in eggs of a piscivorous bird (herring gull Larus argentatus), in muscles of two piscivorous fish (lake trout and walleye Sander vitreus) and of a planktivorous fish (rainbow smelt Osmerus mordax) in the Great Lakes. The results presented a mixed temporal pattern (Fig. 2), with declining biotic $\mathrm{Hg}$ trends in all species in the first few decades (up to about 1995-2000) that matched the declining atmospheric $\mathrm{Hg}$ trend in North America (see Fig. 1). After about 2005, however, trend reversals were detected in most species at some locations. Zhou et al. (2017) also detected a breakpoint at $\sim 2010$ in fish $\mathrm{Hg}$ trends in the Great Lakes, with a significant decreasing trend before 2010 and no trend or an increasing trend since then.

Similar trend results were reported in fish populations across western Canada and the USA. When examining $\mathrm{Hg}$ data on 96,000 fish muscle samples from 206 species in over 4200 lakes, Eagles-Smith et al. (2016) found a significant, rapid decline in length-adjusted tissue $\mathrm{Hg}$ concentrations during the 1970 s, with no subsequent significant trend up to 2012. In all of these studies, the authors attributed the early decline in biotic $\mathrm{Hg}$ to regional and local declines in atmospheric $\mathrm{Hg}$ concentrations and deposition related to regional anthropogenic emissions controls. They suggested that the subsequent trend reversal or lack of a significant trend, was caused by a variety of factors such as increasing local emissions, food web changes, eutrophication, or climate change.

Contrasting biotic $\mathrm{Hg}$ trends have also been reported for other lakes in the same region. When examining temporal fish $\mathrm{Hg}$ trends in hundreds of small lakes in Ontario, Canada, Gandhi et al. (2014) found a general decline in length-adjusted fish muscle $\mathrm{Hg}$ concentrations from the 1970 s to 1990 s for northern pike (Esox lucius), walleye and lake trout, followed by relatively small increases in some lakes starting about 1995-2000. Both the early declining trends and recent increasing trends were more pronounced in northern lakes and in northern pike and walleye compared to lake trout. In contrast, when examining changes in fish muscle $\mathrm{Hg}$ from 873 Ontario lakes, Tang et al. (2013) reported no significant decreases over the past several decades in any of the seven species (walleye, northern pike, lake trout, burbot, smallmouth bass Micropterus dolomieu, whitefish Coregonus clupeaformis and white sucker Catostomus commersonii). Instead, mean fish $\mathrm{Hg}$ concentrations were found to be slightly higher in the period 2005-2010 than in 1974-1981, and were significantly so in northern pike. Such divergent results were also reported in fish $\mathrm{Hg}$ in four small lakes within a national park in northern Minnesota 

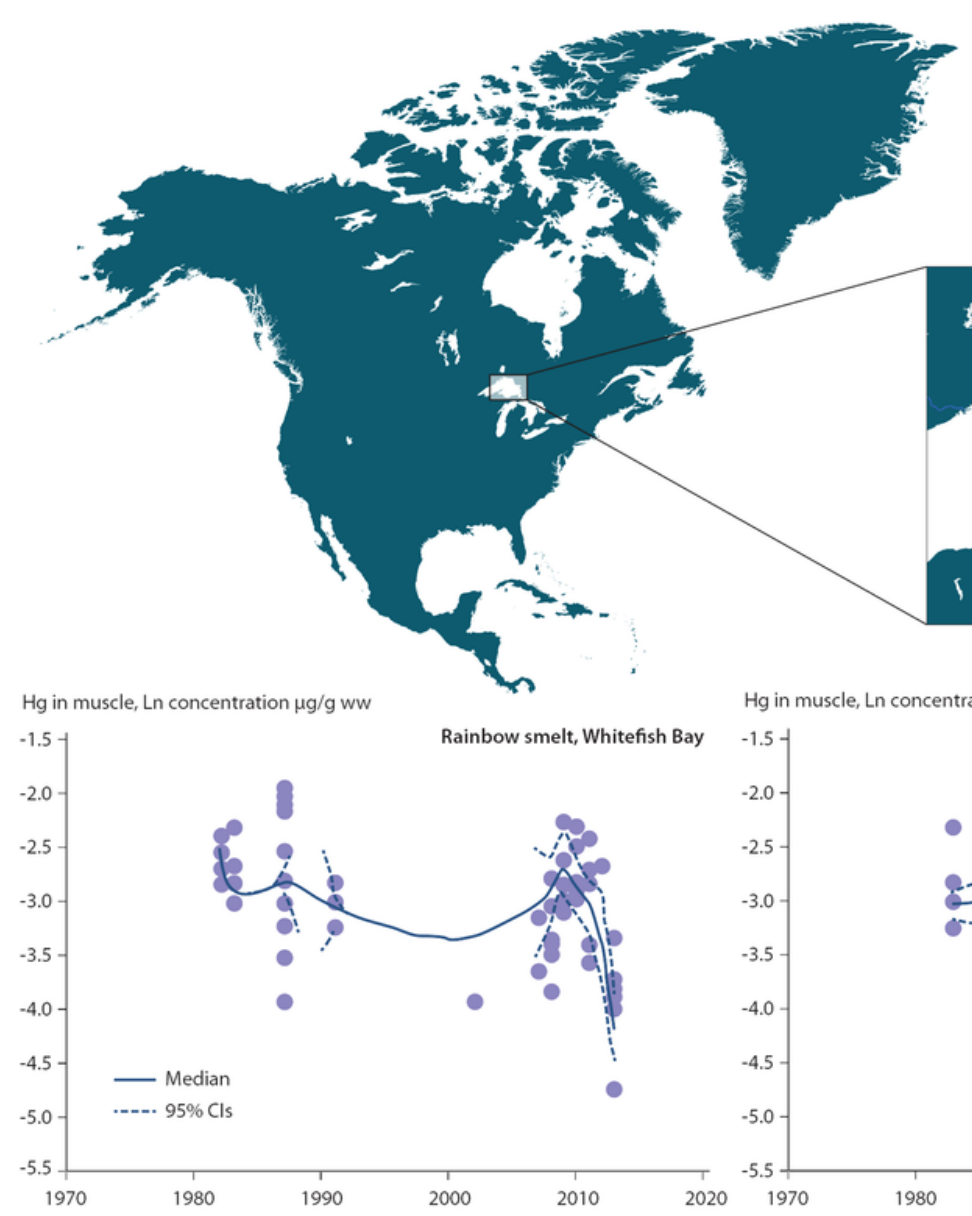

$\mathrm{Hg}$ in egg, Ln concentration $\mu \mathrm{g} / \mathrm{g}$ ww

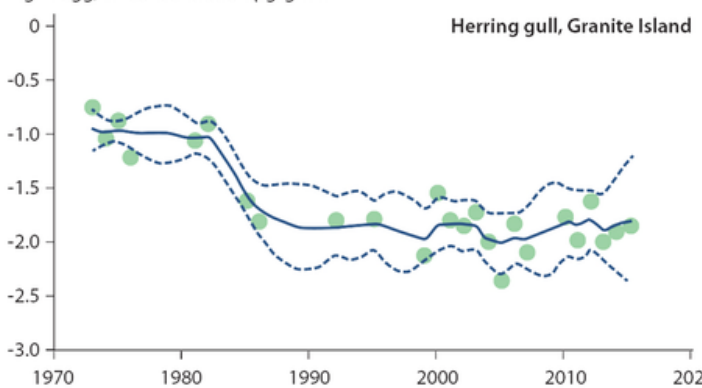

$\mathrm{Hg}$ in muscle, Ln concentration $\mu \mathrm{g} / \mathrm{g}$ ww

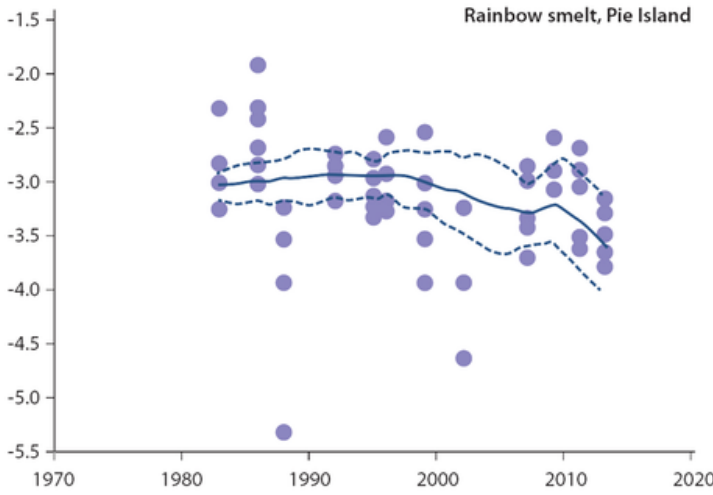

$\mathrm{Hg}$ in egg, Ln concentration $\mu \mathrm{g} / \mathrm{g}$ ww

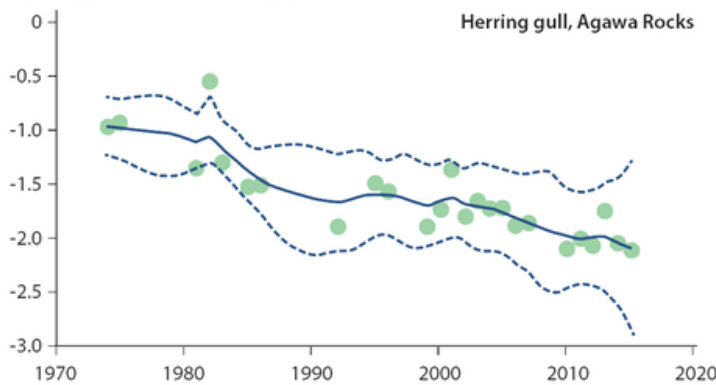

$\mathrm{Hg}$ in muscle, $\mathrm{Ln}$ concentration $\mu \mathrm{g} / \mathrm{g}$ ww

$\mathrm{Hg}$ in muscle, Ln concentration $\mu \mathrm{g} / \mathrm{g} \mathrm{ww}$
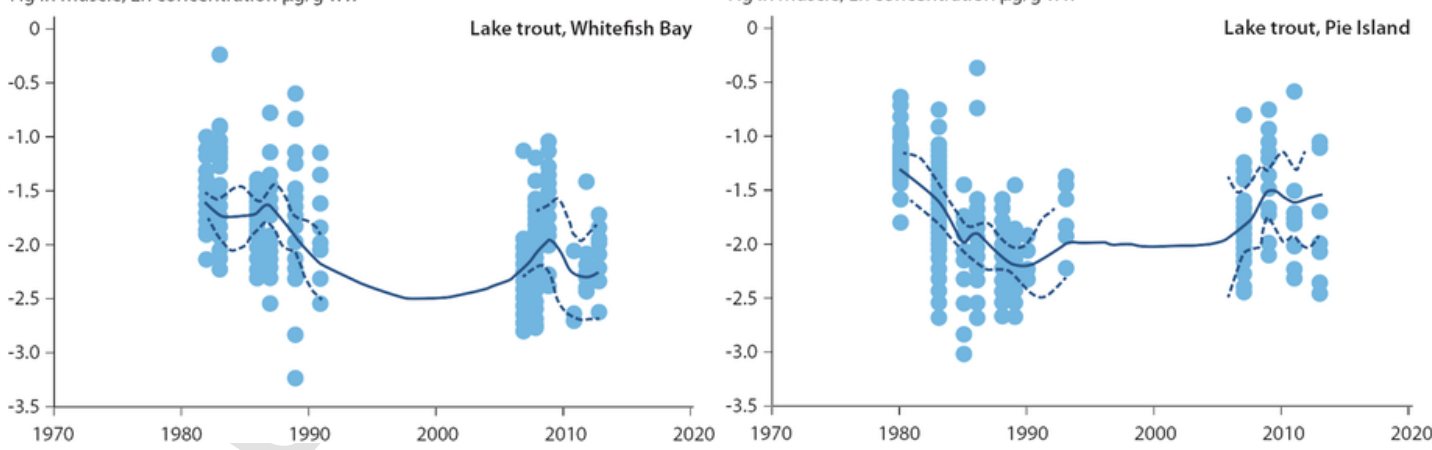

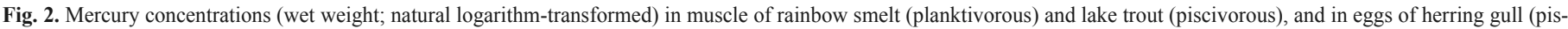

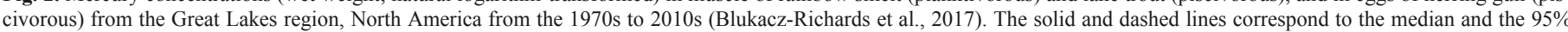
confidence intervals (CIs) of the predicted $\mathrm{Hg}$ concentrations. 
(Brigham et al., 2014) and throughout the State of Massachusetts (Hutcheson et al., 2014) in the USA. Whereas the majority of these lakes showed a decreasing trend in fish $\mathrm{Hg}$ between 2000 and 2010 , a smaller set of lakes showed an increasing or no trend. The diverging trends in fish $\mathrm{Hg}$ among lakes from the same region clearly demonstrate the complexity of ecosystem responses to changes in atmospheric $\mathrm{Hg}$ concentration and deposition, and suggest that other factors besides $\mathrm{Hg}$ inputs, likely related to human and climate induced variability, were more important drivers.

Similarly, a declining trend was found in different populations of the marine species, bluefish (Pomatomus saltatrix), along the northeast coast of the USA. Substantial reductions in muscle $\mathrm{Hg}$, of $\sim 30-40 \%$, were reported when comparing fish caught in the early 1970s with those caught between 1994 and 2011; the New York regional data suggested no change in bluefish $\mathrm{Hg}$ concentrations after 1994 (Fig. 3) (Cross et al., 2015).

Most of these studies did not include carbon and nitrogen isotope data, making it impossible to investigate whether changes in feeding behavior (e.g., prey trophic level and feeding location) influenced the $\mathrm{Hg}$ trends. The value of including trophic dynamic information in the interpretation of $\mathrm{Hg}$ temporal trends was demonstrated by Burgess et al. (2013) in a study of $\mathrm{Hg}$ in herring gull eggs on the eastern Canadian seaboard. Between 1972 and 2008, two sites displayed a trend of significantly declining egg $\mathrm{Hg}$ that was consistent with the declining atmospheric $\mathrm{Hg}$ deposition occurring at that time (see Fig. 1). However, when trophic level changes over time were factored into the analysis using $\delta^{15} \mathrm{~N}$ isotope data, it was found that the $\mathrm{Hg}$ declines were due to feeding behavior shifts. $\delta^{15} \mathrm{~N}$ is a widely-used indictor of the trophic level of species' prey selection, and was highly correlated with egg $\mathrm{Hg}$ in the birds. These results suggest that $\mathrm{Hg}$ in the coastal ecosystem in that region may have remained relatively constant over the past few decades despite the reduction in airborne $\mathrm{Hg}$ fluxes.

\subsection{Case study 2: freshwater fish in Fennoscandia}

Braaten et al. (2017) and Åkerblom et al. (2014) assessed the spatial and temporal trends of $\mathrm{Hg}$ in various species of freshwater fish (e.g., northern pike, Eurasian perch Perca fluviatilis, brown trout Salmo trutta, Arctic char Salvelinus alpinus, roach Rutilus rutilus) during the past 50years (1965-2015) based on 54,560 samples from 2775 lakes across Fennoscandia (Sweden, Finland, Norway, and the Kola Peninsula in Russia). Some of the lakes were impacted by historical, local industrial emissions of $\mathrm{Hg}$ directly to surface water, whereas others were impacted primarily by atmospheric $\mathrm{Hg}$ deposited onto catchment soils as well as water surfaces.

As expected, lakes that were affected by local direct pollution sources had higher mean observed fish $\mathrm{Hg}$ concentrations than lakes that were predominantly affected by long-range atmospherically deposited $\mathrm{Hg}$. When the fish $\mathrm{Hg}$ concentrations were normalized to a standard $1-\mathrm{kg}$ pike, the $\mathrm{Hg}$ concentrations in " $1-\mathrm{kg}$ pike equivalent fish" showed a consistent and significant decreasing trend for the entire database (Fig. 4). This declining trend matches very well with the general declining atmospheric $\mathrm{Hg}$ trend over northern Europe (see Fig. 1). Of particular interest is the finding that the declining fish $\mathrm{Hg}$ trend was much stronger for the entire database than for lakes only impacted by atmospheric $\mathrm{Hg}$ deposition. This could suggest that reduced $\mathrm{Hg}$ emissions, especially a reduction in local emission sources, lead to lower $\mathrm{Hg}$ in fish. However, Braaten et al. (2017) noted that the temporal trends varied with different standardization methods, and cautioned that a better understanding of possible confounding environmental processes (such as the impact of temperature and dissolved organic matter) is needed prior to concluding that the two declining trends are causally linked.

Also of note is that some of the lakes in Sweden were treated with lime in the 1970s and early 1980s to mitigate the impact of acidification. Although liming reduced fish $\mathrm{Hg}$ concentrations (Meili, 1995), fish $\mathrm{Hg}$ concentrations in these limed lakes remained consistently higher than in lakes that were not limed decades after the liming (Åkerblom et al., 2014). The temporal trends in both limed and non-limed lakes were, however, similar ( $\AA$ kerblom et al., 2014).

\subsection{Case study 3: fish in reservoirs in North America and Europe versus China}

Some of the longest time series of aquatic $\mathrm{Hg}$ data exist for man-made reservoirs due to concerns about the effects of impoundment on $\mathrm{Hg}$ methylation rates and thus on fish $\mathrm{Hg}$ concentrations. Although these reservoirs are not natural habitats for aquatic life, they contain abundant fish and invertebrate communities, and support important recreational fisheries in some areas (e.g., in North America and Europe) and large aquaculture operations in others (e.g., in Asia). Extensive studies in the past decades have revealed very different fish $\mathrm{Hg}$ trends in reservoirs in North America and Europe from those in China, neither of which followed the atmospheric $\mathrm{Hg}$ trend.

Studies in North America and Europe have shown that following impoundment, the large influx of flooded vegetation and organic matter in submerged soil stimulates microbial methylation of $\mathrm{Hg}$, result-
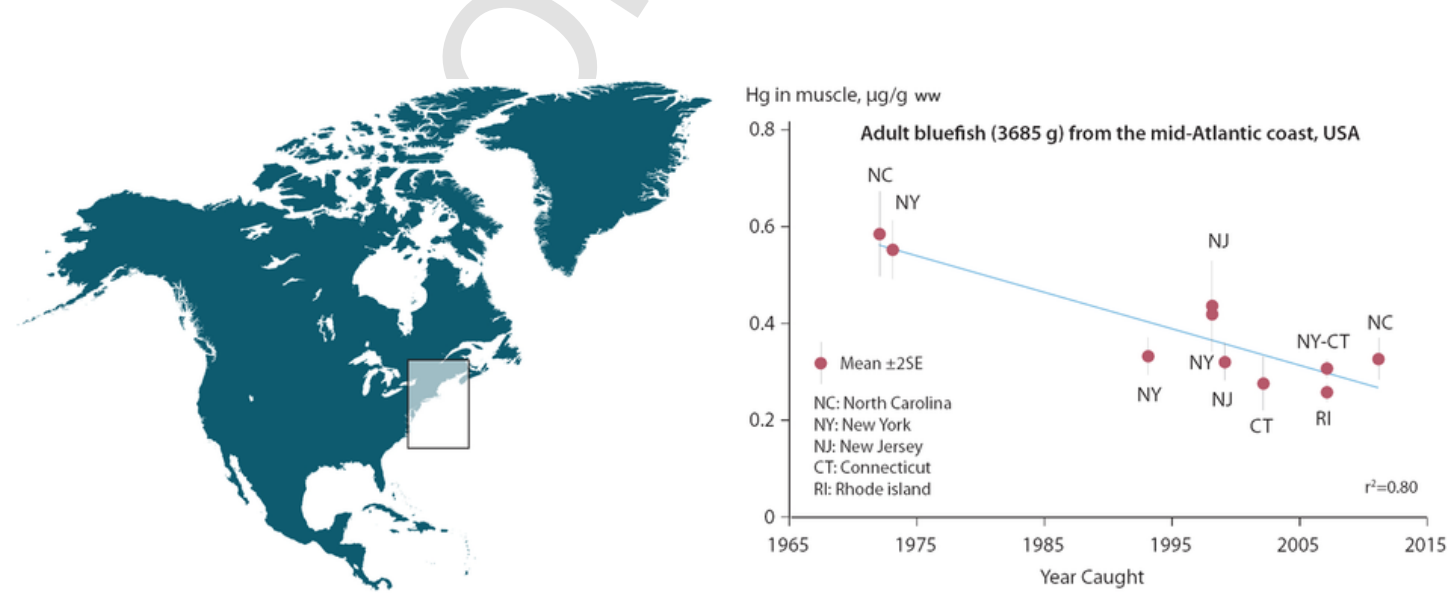

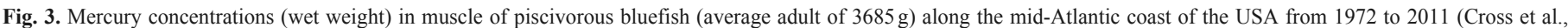
2015). The vertical bars show \pm two times standard errors (SE), and the solid lines represents a linear regression. 

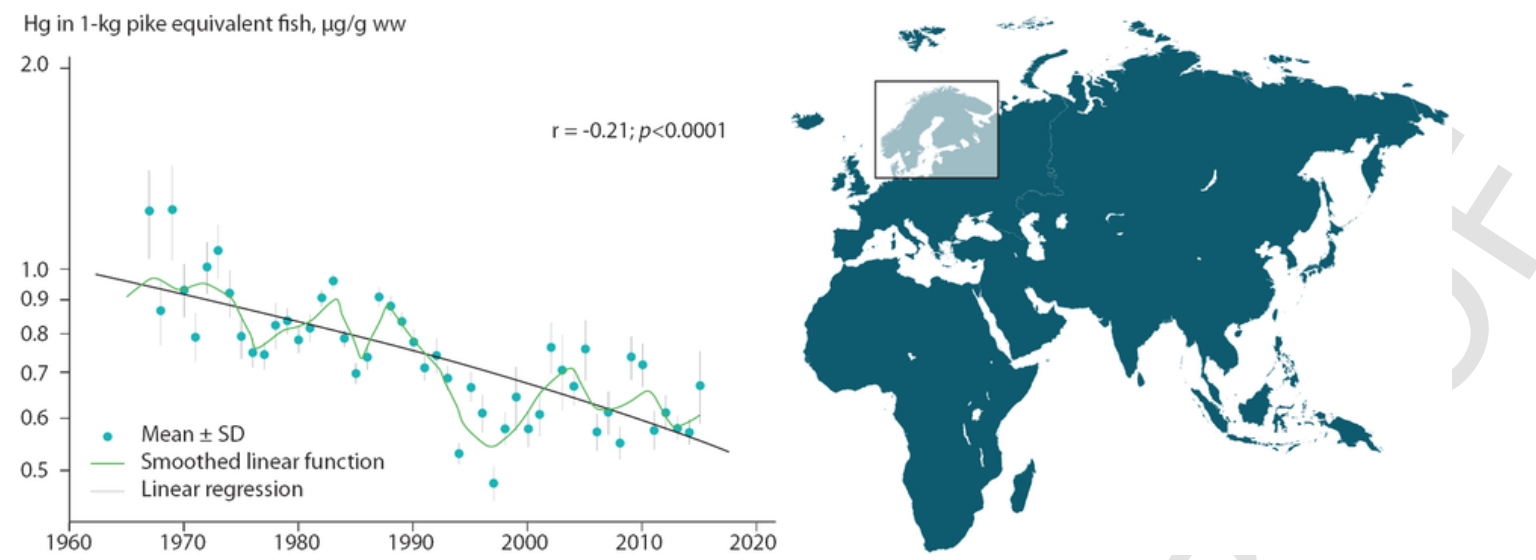

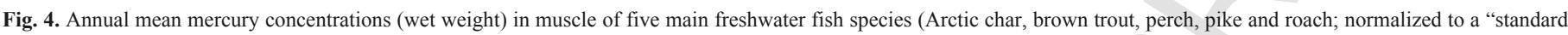

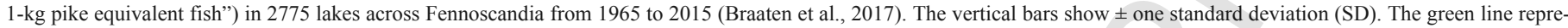

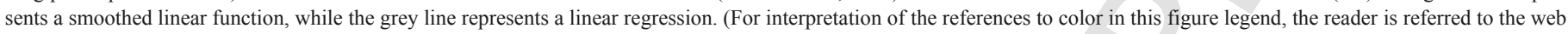
version of this article.)

ing in a sharp increase in fish $\mathrm{Hg}$ due to biomagnification of $\mathrm{MeHg}$ (Bodaly et al., 2007; Hall et al., 2005; Lucotte et al., 1999; St. Louis et al., 2004). Mercury methylation rates and fish $\mathrm{Hg}$ concentrations typically decrease as the reservoir ages and the organic matter further decomposes (Bodaly et al., 2007). This was demonstrated in a recent analysis of the temporal trends of $\mathrm{Hg}$ in a range of fish species from 883 reservoirs across western North America (Willacker et al., 2016). Temporal patterns (normalized for confounding variables such as species and body length) were clearly related to the time elapsed since reservoir impoundment, with maximum fish $\mathrm{Hg}$ concentrations being reached on average three years after the impoundment (Fig. 5). Fish $\mathrm{Hg}$ concentrations thereafter declined relatively rapidly for 4-to-12 years, followed by a monotonic slow decline over many decades. Because the reservoirs were built at different dates over the past 150 years, it may be concluded that the fish $\mathrm{Hg}$ trends are not directly related to changing atmospheric $\mathrm{Hg}$ deposition. Instead, water storage management is shown to be a key factor influencing this temporal pattern. Fish in reservoirs that experienced drawdown dur- ing summer months (May-July) exhibited significantly higher concentrations (up to 11-fold) than fish in reservoirs in which drawdown occurred during other times of the year, likely due to oxidation of reduced sulfide in the sediment while exposed as well as higher microbial activities upon inundation, both of which stimulate methylation of $\mathrm{Hg}$.

Indeed, for reservoirs in China, however, fish $\mathrm{Hg}$ concentrations may be even less connected with atmospheric inputs (Feng et al., 2018; Hsu-Kim et al., 2018). Extensive studies over the past decade on reservoirs in the Wujiang Basin in southwest China, most of which were actively used for aquaculture, have shown that $\mathrm{Hg}$ concentrations in the various fish species studied were remarkably low in the reservoirs along the Wujiang River regardless of the age of the reservoir (Feng et al., 2018). While biodilution and simple (short) food web structures clearly contribute to the generally low fish $\mathrm{Hg}$ concentrations, comparisons of fish $\mathrm{Hg}$ concentrations in reservoirs of different age in the same basin reveal three distinct stages of evolution (primary, intermediate, and advanced stages) due to changes in

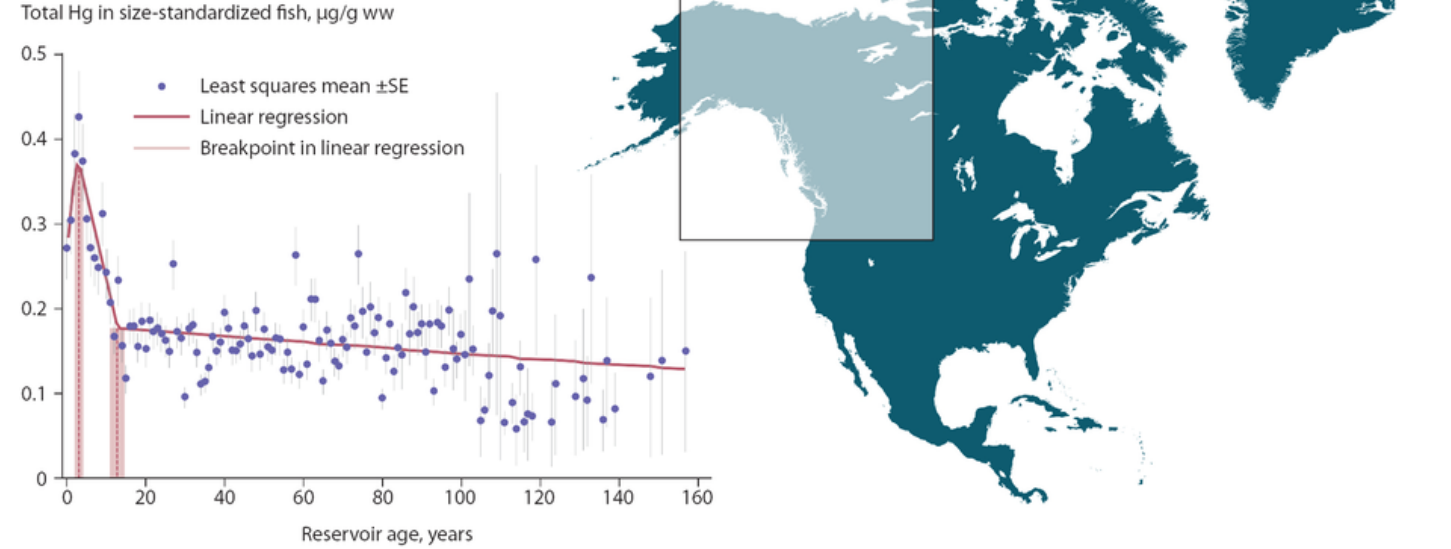

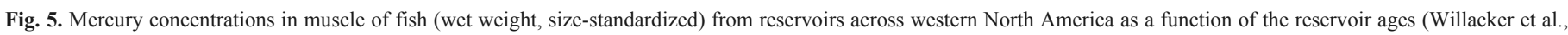

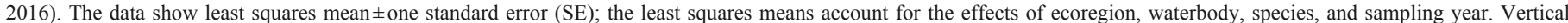

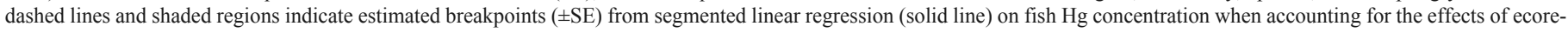
gion, waterbody, species, and sampling year. 
the source and concentration of organic matter in the submerged soil/ sediment as the reservoir ages and cage aquaculture activities increase (Feng et al., 2018). The newly constructed reservoirs in the Wujiang Basin are not active sites of net $\mathrm{Hg}$ methylation due to the low organic carbon content in the submersed soils and/or low primary productivity (Meng et al., 2010; Yao et al., 2011). Consequently, during the primary stage the newly constructed reservoirs are not a net source of $\mathrm{MeHg}$ and instead represent a net sink (Zhao et al., 2017; Feng et al., 2018). As these reservoirs become more productive (mesotrophic to eutrophic) with time, the organic matter content in the sediment increases due to continuous increases in autochthonous productivity due to the cage aquaculture activities. This tends to promote in situ $\mathrm{Hg}$ methylation, and as such reservoirs at this intermediate stage have transited from a net $\mathrm{MeHg}$ sink to a net $\mathrm{MeHg}$ source. Over the long-term evolution of the reservoir, primary productivity continues to increase and the reservoir will eventually become eutrophic. Phytoplankton-derived organic matter, and fish food and feces, become significant sources of organic matter input to the surface sediments. The increased oxygen consumption during fresh organic matter degradation causes progressively more anoxic conditions at the sediment-water interface (Meng et al., 2010; Meng et al., 2016) that promotes the microbial $\mathrm{Hg}$ methylation processes during this advanced stage of evolution, when both the surface sediment and the hypolimnetic water were sites of net $\mathrm{MeHg}$ production (Feng et al., 2009; Meng et al., 2010; Meng et al., 2016). Thus, in contrast to fish in North American reservoirs, and despite the relatively high atmospheric $\mathrm{Hg}$ loading across much of China, fish $\mathrm{Hg}$ concentrations in Chinese impoundments reflect within-impoundment processes, especially organic matter loadings to sediments, water/soil quality, food web structure, and biodilution, rather than atmospheric inputs (Feng et al., 2018).

\subsection{Case study 4: the Arctic}

Rigét et al. (2011) summarized all available temporal Hg datasets on Arctic biota up to about 2009, and found that some species in some locations had shown significant increases over recent decades, whereas others with closely adjacent or overlapping distributions exhibited decreases or non-significant changes. Most of the increasing biotic $\mathrm{Hg}$ trends occurred in marine species in the North American and west Greenlandic sector of the Arctic, whereas most declining trends were observed in east Greenlandic and European Arctic biota. This regional dichotomy is clearly seen in the hair of polar bears (Ursus maritimus), and has been suggested to be due to increased emissions from Asia entering the western Arctic coincident with decreasing emissions from North America and Europe in the eastern Arctic (Dietz et al., 2006).

A few additional studies have since been published. Rigét et al. (2012) analyzed temporal trends of Hg in livers of ringed seals (Pusa hispida) collected from the early 1980s to 2010 from Greenland. Increasing concentrations of $\mathrm{Hg}$ were found in ringed seals in two out of three Greenlandic seal populations (Central East and Northwest Greenland), rising at a rate of $10.3 \%$ per year and $2 \%$ per year, respectively. In addition to age and trophic position, the study showed that the Atlantic Oscillation Index, a parameter related to climate variability, was positively associated with $\mathrm{Hg}$ concentrations in seals although the specific mechanism involved was not clear. Similarly, the long-term variability in beluga $\mathrm{Hg}$ from the Beaufort Sea region has been shown to be associated, with a lag time, with the Pacific Decadal Oscillation (Loseto et al., 2015).

By analyzing $\mathrm{Hg}$ in the teeth of polar bear from Svalbard in the Norwegian Arctic, Aubail et al. (2012) reported a decreasing trend in
Hg concentration over the period 1964-2003 (Fig. 6B). Since no temporal changes were found in tooth $\delta^{15} \mathrm{~N}$ and $\delta^{13} \mathrm{C}$, they concluded that the decrease of $\mathrm{Hg}$ was not due to changes in trophic dynamics; instead, it was more likely to be due to a lower environmental $\mathrm{Hg}$ exposure in the region. McKinney et al. (2017) also reported a significant declining trend in hair $\mathrm{Hg}$ of the southern Beaufort Sea polar bear population, at an average rate of $-13 \%$ per year, between 2004 and 2011. This finding differs from the general west-east trend patterns in Arctic biota $\mathrm{Hg}$ noted above. However, only male Polar Bears in the southern Beaufort Sea area exhibited significant decreases; females from the same area showed no significant trend. Mercury concentrations in the bears' main prey (ringed seal) also showed no change up to 2007 (Gaden et al., 2009), which argues against changes in $\mathrm{Hg}$ inputs or the biogeochemical $\mathrm{Hg}$ cycle as contributing to the decline. Analyses of body condition and diet led to the conclusion that the bears' $\mathrm{Hg}$ trend was due to changing foraging patterns over time and not to alteration in environmental $\mathrm{Hg}$ concentrations (McKinney et al., 2017).

Braune et al. (2014) reported the temporal trend of $\mathrm{Hg}$ in thick-billed murre (Uria lomvia) eggs from Coats Island, northern Hudson Bay, and Prince Leopold Island in Lancaster Sound, Nunvut. Although there was no significant change in $\mathrm{Hg}$ concentrations in murre eggs from Coats Island from 1993 to $2013, \delta^{15} \mathrm{~N}$ values for the eggs were found to be decreasingly significantly, suggesting a decline in trophic position for the bird due to a dietary switch from Arctic cod (Boreogadus saida) to capelin (Mallotus villosus). After adjusting egg $\mathrm{Hg}$ concentrations for the decline in trophic position, time trends in $\mathrm{Hg}$ concentration at Coats Island changed from non-significant to significantly increasing. In contrast, at Prince Leopold Island, after adjustment for trophic position the egg $\mathrm{Hg}$ time trends changed from non-significant to significantly decreasing over the same period. These results suggest that in addition to trophic change in diet, there may have been other geographic factors at play that influenced $\mathrm{Hg}$ concentrations at the base of the marine food web, such as differences in $\mathrm{Hg}$ deposition, or in $\mathrm{Hg}$ bioavailability related to climate change.

Subsequently, Braune et al. (2016) updated the Hg trends in High Arctic seabird eggs at Prince Leopold Island to 2014 for five species: thick-billed murre, northern fulmar (Fulmarus glacialis), black-legged kittiwake (Rissa tridactyla), black guillemot (Cepphus grylle), and glaucous gull (Larus hyperboreus). The first three species' eggs had been collected from the Island as early as 1975, while the guillemots and gulls were sampled from 1993 to 2013. Egg Hg trends were adjusted for possible shifts in trophic position of the birds using $\delta^{15} \mathrm{~N}$ data. Adjusted $\mathrm{Hg}$ concentrations in eggs of murres, fulmars and kittiwakes increased from 1975 to the 1990 s, followed by a plateauing or slight decline from the 1990s to 2014 (Fig. 6A). However, the kittiwake trend was strongly influenced by the 1975 samples; when these were excluded, kittiwake eggs displayed a significant decreasing trend from 1976 to 2013. Trends in the eggs of murres, fulmars, kittiwakes, and guillemots had negative slopes between 1993 and 2013. The pattern in glaucous gull eggs was different: decreasing by 50\% from 1993 to 2003 before increasing again.

Braune et al. (2016) concluded that the general increasing trends in egg $\mathrm{Hg}$ during the 1970s and 1980s were consistent with atmospheric $\mathrm{Hg}$ increases over the Arctic during that period. They noted that the migratory habits of the five bird species, which overwinter in different southern regions away from Lancaster Sound, complicated interpretation of the reasons for the temporal trends. Environmental $\mathrm{Hg}$ changes in their wintering areas could have been different to those in the Arctic. Interpretation is also complicated by significant differences in the findings from glacier archives of atmospheric $\mathrm{Hg}$ on the western and eastern edges of the North American Arctic. 


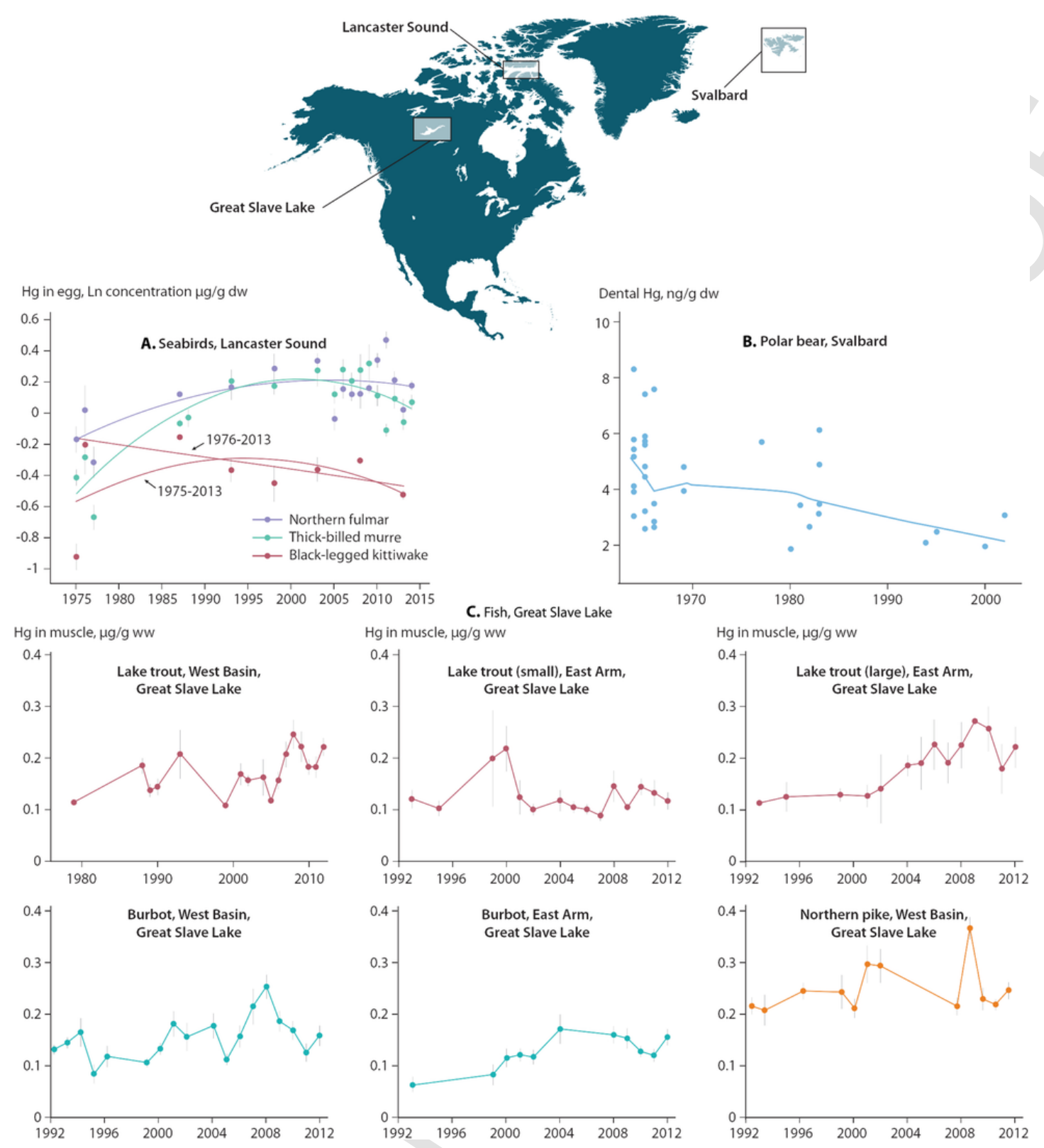

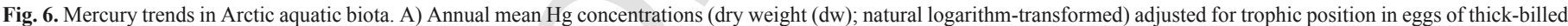

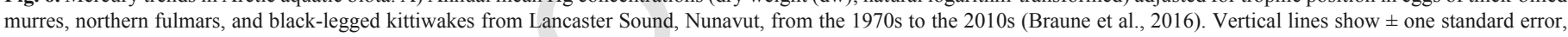

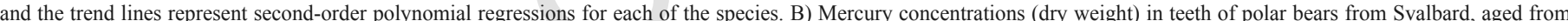

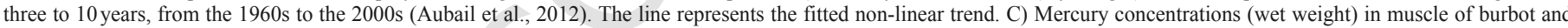

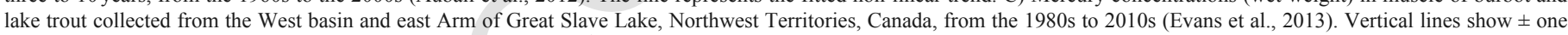
standard error.

Greenland glacial snow/firn (Faïn et al., 2009) showed a monotonic decline in atmospheric GEM concentrations during the 1970s and 1980 s, following peak concentrations in the 1950s to 1960s. Glacial snow and ice core reconstructions of atmospheric $\mathrm{Hg}$ deposition from Mt. Logan (Yukon) showed increases in deposition through the 1990s, which could be an indication of increasing trans-Pacific contamination from Asia (Beal et al., 2015). Overall, these data, especially the declining GEM trend on Greenland through the 1970s and 1980s, are inconsistent with the conclusions of Braune et al. (2016). However, the flat or slightly declining egg $\mathrm{Hg}$ data from about 1990 onwards is consistent with the recent modelling of atmospheric GEM in the Arctic (see Fig. 1). Zheng (2015), on the other hand, reported that 20th-century total $\mathrm{Hg}$ accumulation in a Greenland ice core was relatively constant until increasing during the 1970 s to 2000 s, a pattern similar to those in most of the bird species but not in agreement with the (Zhang et al., 2016) modelling. Thus, uncertainty about the actual trends in Arctic atmospheric $\mathrm{Hg}$ deposition is a limiting factor in assessing agreement between environmental and biological $\mathrm{Hg}$ trends in this region.

In Great Slave Lake in the western Canadian Arctic, temporal trends of $\mathrm{Hg}$ in lake trout, burbot, and northern pike were monitored irregularly between the late 1980s or early 1990s and 2012 (Fig. 6C) (Evans et al., 2013). Muscle Hg data were adjusted for fish length, but not for trophic shifts over time. Mercury concentrations generally 
increased over time in lake trout and burbot, but not in northern pike, with considerable interannual variation. These increasing or flat patterns are inconsistent with atmospheric GEM concentrations and wet deposition fluxes that were declining at the time (see Fig. 1) and with the Mt. Logan atmospheric deposition record of Beal et al. (2015). Statistical analysis of climate factors suggested that varying annual mean air temperatures, and particularly cold season temperatures, were related to the fish $\mathrm{Hg}$ patterns although a precise mechanism linking temperature to fish $\mathrm{Hg}$ could not be elucidated (Evans et al., 2013).

\section{Causes of the divergence between aquatic biota and atmospheric Hg trends}

There are marked differences between century-scale and recent decadal datasets in terms of how well atmospheric and biotic $\mathrm{Hg}$ trends track each other. The century-scale biotic $\mathrm{Hg}$ trends since about 1850 (from the Arctic; Dietz et al., 2009) generally matched the increasing atmospheric $\mathrm{Hg}$ deposition trends recorded in remote glacial ice cores and other natural archives (Beal et al., 2015; Kang et al., 2016; Zheng, 2015). Starting in the mid- to late-19th century, and shortly after major anthropogenic uses and global-scale emissions of $\mathrm{Hg}$ became more common (Outridge et al., 2018), Hg concentrations in the atmosphere and in aquatic biota increased steadily up to maxima typically attained at about the 1970s-1980s (Dietz et al., 2009; Rigét et al., 2011). The longer-term biotic datasets from the Arctic thus clearly indicate the effects of anthropogenic contamination of aquatic systems over the century or more since about 1850 .

However, as anthropogenic emissions to air began to stabilize after the 1980 s, it became increasingly apparent that a divergence between the biotic and atmospheric $\mathrm{Hg}$ trends was developing in some areas, and in some co-occurring species. In other areas and species, however, the atmospheric and biotic trends continued synchronously. The divergent patterns between the atmospheric and biotic $\mathrm{Hg}$ trends have become more apparent over the past two decades, as atmospheric and biological monitoring became more widespread and frequent.

Fundamentally, the divergence between the biotic and atmospheric mercury trends may be generally attributed to the large inventories of legacy $\mathrm{Hg}$ in soil and ocean reservoirs, and the exceptional sensitivity of $\mathrm{Hg}$ biogeochemical cycling to changes in physical (e.g., temperature, light, hydrology), geochemical (e.g., $\mathrm{pH}$, redox status, complexing ligands), biological (e.g., feeding behavior of an organism) and ecological (e.g., primary productivity, microbial processes, food web structure and dynamics) conditions (Table 1; see also Hsu-Kim et al., 2018). Many of the effects have been recently exacerbated by climate change. Some of the major processes that trigger changes in these conditions, and thus cause the decoupling between biotic and environmental $\mathrm{Hg}$, include changes in the terrestrial environment and landscape, changes in the aquatic ecosystem, and climate change.

\subsection{Changes in the terrestrial environment and landscape}

Globally the terrestrial environment represents the largest inventory of $\mathrm{Hg}(\sim 950 \mathrm{kt})$, with $\sim 150 \mathrm{kt}$ stored in surface organic soils (Outridge et al., 2018). Terrestrial biota are much less prone to $\mathrm{Hg}$ bioaccumulation as the conversion of inorganic $\mathrm{Hg}$ to $\mathrm{MeHg}$ is not favored in the terrestrial environment (Fitzgerald and Lamborg, 2014). Also, on a global scale, anthropogenic inputs have altered the $\mathrm{Hg}$ inventory in the soils to a lesser degree than in the oceans due to the naturally large mass of $\mathrm{Hg}$ that is present in terrestrial systems (Outridge et al., 2018). However, major changes in landscape and
Table 1

Properties of mercury $(\mathrm{Hg})$ and their implications for its biogeochemistry. (Modified from Wang and Zhang, 2013).

\begin{tabular}{ll}
\hline Property & Implications \\
\hline Redox between $\mathrm{Hg}^{0}$ and $\mathrm{Hg}^{\mathrm{II}}$ & $\begin{array}{l}\text { Sensitive to changes in redox and } \mathrm{pH} \\
\text { conditions; sensitive to photochemical and } \\
\text { microbial processes } \\
\text { Sensitive to changes in temperature; long-range } \\
\text { atmospheric transport; a global problem }\end{array}$ \\
nigh vapor pressure of $\mathrm{Hg}^{0}$ & $\begin{array}{l}\text { needing global solutions } \\
\text { Strong affinity to ligands (e.g., reduced }\end{array}$ \\
$\mathrm{Hg}^{2+}$ ions being one of the & $\begin{array}{l}\text { sulfides, halogens); sensitive to changes in } \\
\text { organic carbon and redox conditions }\end{array}$ \\
softest Lewis acids & $\begin{array}{l}\text { Sensitive to changes in temperature, organic } \\
\text { carbon, nutrients, redox and microbial } \\
\text { processes; direct source control of }\end{array}$ \\
Methylation is primarily & methylmercury difficult \\
microbial, with & Sensitive to changes in temperature, food web \\
methylmercury being the & structure and dynamics
\end{tabular}

land-use in the watershed, such as urbanization, agricultural activities, flooding, damming, and deforestation, may affect the net release of soil $\mathrm{Hg}$ to downstream aquatic systems (inland and coastal). More importantly, they also change the organic carbon flux from watersheds and redox conditions that directly influence $\mathrm{Hg}$ methylation processes in adjacent aquatic systems. The importance of such changes is perhaps best demonstrated by reservoir construction in the watershed. As shown in Case Study 3, fish $\mathrm{Hg}$ concentrations in reservoirs are primarily controlled by the influx and dynamics of terrestrially-derived organic carbon and $\mathrm{Hg}$, and bear almost no relationship with trends in atmospheric $\mathrm{Hg}$ concentrations or deposition, even decades after reservoir impoundment.

\subsection{Changes in the aquatic ecosystem}

As $\mathrm{MeHg}$ biomagnifies in the aquatic food web (i.e., MeHg concentration increases from prey to predator), any changes in ecosystem structure, function, and dynamics may result in major changes in $\mathrm{Hg}$ concentrations within the ecosystem. Processes such as acidification/liming (Case Study 2) and eutrophication (see Case Study 3) affect $\mathrm{MeHg}$ production by altering $\mathrm{Hg}$ speciation and bioavailability, as well as $\mathrm{Hg}$ food-chain transfer and biotic $\mathrm{Hg}$ concentrations by altering species composition, biomass and growth rates (e.g., Clayden et al., 2013; Jardine et al., 2013). Aquaculture, overfishing, and invasion of non-native species can change not only the nutrient status of an aquatic ecosystem, but also the structure, function, and dynamics of food webs, and thus could result in major changes in biota $\mathrm{Hg}$.

\subsection{Climate change}

On the global scale, climate change may be the most prevalent contributor to the divergence between biotic and environmental $\mathrm{Hg}$ trends. Changes in water temperature alone could affect mercury bioaccumulation in various ways. For instance, temperature increases could lead to changes in bioenergetics of primary consumers and fish that leads to higher ingestion but has less effect on elimination processes, resulting in an increase in biota $\mathrm{Hg}$ concentrations. The impact of climate change on biotic $\mathrm{Hg}$ is perhaps most profoundly felt in the Arctic, where rapid climate warming has resulted in dramatic changes in many biogeochemical and ecological processes that drive $\mathrm{Hg}$ cycling (Chen et al., 2018; Stern et al., 2012; Wang et al., 2010). For instance, the rapid decline in the aerial coverage and thickness of Arctic sea ice and the replacement of multi-year sea ice by first-year sea ice have been shown to influence $\mathrm{Hg}$ distribution 
and transport across the ocean-sea ice-atmosphere interface, as ice prevents elemental $\mathrm{Hg}$ evasion and leads to a buildup of $\mathrm{Hg}^{0}$ under the ice (Dimento et al., 2018; Andersson et al., 2008), and can alter $\mathrm{Hg}$ methylation and demethylation rates, promote changes in primary productivity, and shift food web structures (bottom-up processes) (Beattie et al., 2014; Chaulk et al., 2011; Heimbürger et al., 2015; Wang et al., 2017). Arctic tundra plants have been shown to actively take up GEM from the atmosphere, leading to unexpectedly high $\mathrm{Hg}$ accumulation in tundra soils (Obrist et al., 2017). A warming climate thus will not only affect the tundra accumulation of atmospheric $\mathrm{Hg}$, but also the amount of $\mathrm{Hg}$ that can be delivered from the watershed to the Arctic freshwater and marine ecosystems via snow melt and riverine discharge. The very large mass of mainly natural $\mathrm{Hg}$ in northern permafrost deposits, which is projected to be steadily released with further climate warming (Schuster et al., 2018), may profoundly affect biotic $\mathrm{Hg}$ concentrations around the Northern Hemisphere especially as large amounts of organic carbon that may stimulate $\mathrm{Hg}$ methylation rates will be simultaneously released.

Changes in animal social behavior associated with changing sea-ice regimes can also affect dietary exposure to $\mathrm{Hg}$ (top-down processes) (Stern et al., 2012). As shown in Case Study 4, the trophic position of thick-billed murre from Coats Island in northern Hudson Bay has declined, presumably due to feeding increasingly on capelin instead of Arctic cod (Braune et al., 2014). However, the population's egg $\mathrm{Hg}$ concentrations did not change significantly between 1993 and 2013; to explain this stable trend, the availability of $\mathrm{MeHg}$ in the environment and efficiency of $\mathrm{Hg}$ food web transfer must have increased. It has also been suggested that climate warming may cause a shift in energy flow from benthic to pelagic food webs as aquatic productivity increases in high Arctic lakes. Since zooplankton species such as Daphnia contain higher $\mathrm{MeHg}$ than benthic organisms, this shift could increase $\mathrm{Hg}$ transfer in the food web (Chetelat and Amyot, 2008). The impact of climate change on biotic $\mathrm{Hg}$ has also been observed in lower latitude regions (e.g., Pinkney et al., 2014).

\section{Evolution of the relationship between atmospheric and biotic Hg concentrations}

Wang et al. (2010) and Wang and Zhang (2013) proposed that the divergence between biotic and environmental $\mathrm{Hg}$ trends is an indication that an aquatic ecosystem has entered a new 'paradigm' in which the key controls on $\mathrm{Hg}$ bioaccumulation have switched from being 'emissions-driven' to 'processes-driven'. This switch occurs because the biotic $\mathrm{Hg}$ concentrations in an aquatic ecosystem are influenced not only by $\mathrm{Hg}$ influx (natural or anthropogenic) to the system, but also by the internal processes in the ecosystem that control the recycling, speciation, bioavailability, methylation and biological uptake of $\mathrm{Hg}$. As the accumulated mass of 'legacy' $\mathrm{Hg}$ in a water body becomes large relative to the loading rate of newly emitted $\mathrm{Hg}$, the internal biogeochemical processes that control its permanent removal (e.g., burial), re-emission, or uptake into the biota, increasingly become the determining steps in bioavailability and bioaccumulation.

The changing relationship over time between atmospheric $\mathrm{Hg}$ concentrations (or deposition) and biotic $\mathrm{Hg}$ is shown in Fig. 7. Prior to anthropogenic influences (the exact timeline is subject to debate; Outridge et al., 2018), when $\mathrm{Hg}$ emissions were at their natural level, the flux of $\mathrm{Hg}$ to the aquatic system was generally low, and so were its biotic concentrations (Phase I - 'Natural background'). At around the mid-19th century, however, as rapid industrialization resulted in a sharp increase in anthropogenic $\mathrm{Hg}$ emissions, aquatic biota $\mathrm{Hg}$ concentrations responded rapidly due to increasing $\mathrm{Hg}$ deposition, exposure and uptake of $\mathrm{Hg}$ from a small but growing environmental $\mathrm{Hg}$
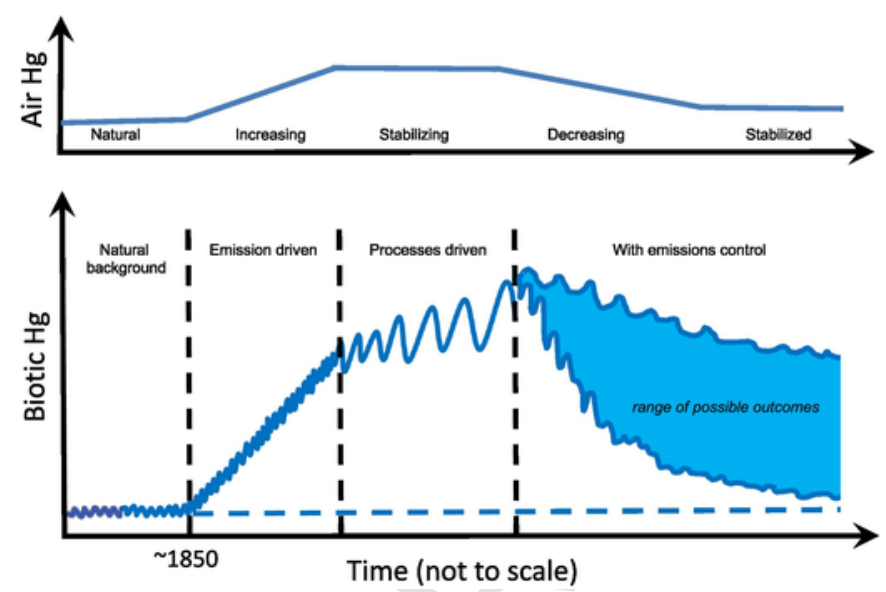

Fig. 7. A schematic representation of evolution in the $\mathrm{Hg}$ concentrations in the air (top) and aquatic biota (bottom), showing changes over time in the principal drivers of $\mathrm{Hg}$ bioaccumulation. The figure is updated from Wang et al. (2010). See the text for details.

inventory (Phase II - 'Emissions-driven'). This phase is clearly seen in long-term retrospective studies of $\mathrm{Hg}$ concentrations in Arctic biota (Dietz et al., 2009). Once an aquatic ecosystem has accumulated sufficient $\mathrm{Hg}$, additional increases in $\mathrm{Hg}$ influx become secondary to the amount that has been accumulated in the system after decades to centuries of loading (i.e., legacy $\mathrm{Hg}$ ). Bioaccumulation then draws predominantly on this legacy $\mathrm{Hg}$, which is operated on by the internal biogeochemical processes (Phase III - 'Internal Processes-driven'). Throughout these three phases, biogeochemical processes (shown as sine-wave 'noise' in Fig. 7) determine the transport and transformation of $\mathrm{Hg}$ from the abiotic part of the ecosystem to biota. But it is in Phase III that these processes emerge to create a variability that is large enough to obscure the effect of the current external $\mathrm{Hg}$ inputs, and hence produce the divergence between biotic and atmospheric $\mathrm{Hg}$ trends (Wang et al., 2010).

In the period following the Minamata Convention, a new phase, Phase IV, can be envisioned (see Fig. 7) which is based on observations of biotic $\mathrm{Hg}$ trends in the recent past, as discussed above, and model predictions of future seawater $\mathrm{Hg}$ concentration trends. As anthropogenic $\mathrm{Hg}$ emissions decrease, atmospheric $\mathrm{Hg}$ concentrations will decrease and eventually stabilize at a new steady state. However, revolatilization of part of the large quantity of legacy anthropogenic $\mathrm{Hg}$ presently contained in the world's oceans and soils, and its recycling between oceans, soils and the atmosphere, means that atmospheric and seawater $\mathrm{Hg}$ concentrations are likely to decrease much more slowly than future changes in $\mathrm{Hg}$ emissions (Sunderland and Mason, 2007; Sunderland and Selin, 2013). While biotic Hg concentrations are also projected to decrease over the long term, the current phase of 'processes-driven' bioaccumulation dictates that it will take much longer to establish a new steady-state in biotic $\mathrm{Hg}$.

The biotic $\mathrm{Hg}$ concentrations at the new steady-state are also likely to remain above the Holocene background levels for an extended period after atmospheric $\mathrm{Hg}$ levels have returned to natural levels, because of the continued presence of legacy $\mathrm{Hg}$ in aquatic and terrestrial systems. In the shorter term, in fact, aquatic biotic $\mathrm{Hg}$ concentrations in many instances, especially in some of the larger, deeper marine ecosystems, are likely to continue to increase despite recent emission controls (Sunderland and Selin, 2013). Biota in smaller waterbodies, such as lakes and coastal marine systems with restricted water mass turnover, are more likely to respond relatively rapidly to emissions controls because of the smaller mass of legacy $\mathrm{Hg}$ contained there relative to the decreased anthropogenic $\mathrm{Hg}$ loadings. 
Examples of this long and 'uneven' recovery in biotic $\mathrm{Hg}$ can be found following the impoundment of a river, or after 'de-acidification' of a lake. As shown in Case Study 3, fish $\mathrm{Hg}$ in reservoirs decreased a few years after the impoundment, but remained above the pre-impoundment concentrations even after more than a century (see Fig. 5). In the 1970s, lime was applied to many Swedish lakes that were acidified due to atmospheric acid deposition, to help restore the lake ecosystem. Following the liming, fish $\mathrm{Hg}$ in those lakes declined by $10-20 \%$ by the 1990 s (Meili, 1995) and continued to decline to the present day (Akerblom et al., 2014). Yet, more than 30 years after the liming, fish $\mathrm{Hg}$ concentrations in these lakes remained considerably higher (twice as high on average) than those in lakes that were not impacted by acidification (and not subject to liming) (Åkerblom et al., 2014).

\section{Implications for evaluating the effectiveness of the Minamata Convention}

Reports of biotic $\mathrm{Hg}$ trends not following the atmospheric $\mathrm{Hg}$ trends in recent decades should not be regarded as discouraging news when considering the efficacy of regulations to reduce atmospheric and other releases of $\mathrm{Hg}$. The fact that effective $\mathrm{Hg}$ emission control is expected to be followed by long delays, in some cases, before an ensuing reduction is seen in food web $\mathrm{Hg}$ concentrations makes it all the more pressing to control and reduce $\mathrm{Hg}$ emissions as early as possible (Chen et al., 2018; Wang et al., 2010).

Nonetheless, policy-makers should be prepared for the fact that the reductions in biotic $\mathrm{Hg}$ concentrations and human $\mathrm{Hg}$ exposure via aquatic food-chains are likely to be uneven and predictable only in the most general way, both in terms of their timing and in the degree of reduction. Different species within the same region, or the same species in different regions, can be expected to show quite different trajectories of tissue $\mathrm{Hg}$ over time, because of the unpredictable consequences of coincidental environmental or ecological process changes. Clearly, based on the recent literature reviewed above, no single species can be expected to reliably reflect the impact of reductions in anthropogenic emissions. Therefore, biomonitoring efforts designed to evaluate the effectiveness of the Minamata Convention in reducing biotic $\mathrm{Hg}$ concentrations should include multiple species occupying different ecological and geographical niches. In particular, piscivorous fish and small prey fish (e.g., young of the year perch) that are widely distributed across ecosystems and continents should be monitored, as they could serve as a better proxy of change (Mason et al., 2005; Wiener et al., 2007). Continuation of existing biological Hg monitoring programs should focus on supporting the longest and most statistically powerful datasets, because these will reflect any future changes in concentrations with greater confidence than short-term or high-variance datasets (Bignert et al., 2004). The collection of essential ancillary biological and ecological data (such as body length or weight, and trophic position using stable nitrogen isotope ratios), which will help to interpret observed changes in tissue $\mathrm{Hg}$, should also be mandatory.

\section{Acknowledgement}

This paper was prepared as a contribution to the United Nations Environment Programme's Global Mercury Assessment, and we thank all of our colleagues who participated in this process, particularly G. Futsaeter and E. Toda (UNEP), S. Wilson (AMAP) and J. Munthe (IVL Swedish Environmental Research Institute). The figures were redrawn by S. Duckworth.

\section{Funding sources}

The work was financially supported by UNEP, and by support from the Canada Research Chairs program (F.W.) and the Geological Survey of Canada (P.M.O.). R.P.M.'s contribution was partially supported by the National Science Foundation's Chemical Oceanography program (Grant 1634048). The authors declare that they have no competing interest.

\section{References}

Åkerblom, S., Bignert, A., Meili, M., Sonesten, L., Sundbom, M., 2014. Half a century of changing mercury levels in Swedish freshwater fish. Ambio 43 (Suppl. 1), 91-103.

AMAP, 2010. Updating Historical Global Inventories of Anthropogenic Mercury Emissions to Air. Technical Report No. 3. Arctic Monitoring and Assessment Programme (AMAP), Oslo, Norway.

AMAP/UNEP, 2013. Technical Background Report for the Global Mercury Assessment 2013. Arctic Monitoring and Assessment Programme (AMAP), Oslo, Norway, and United Nations Environment Programme (UNEP), Geneva, Switzerland, 263

AMAP/UNEP, 2019. Global Mercury Assessment - 2018. Arctic Monitoring and Assessment Program (AMAP), Oslo, Norway, and United Nations Environment Programme (UNEP), Geneva, Switzerland, (in press).

Ariya, P.A., Amyot, M., Dastoor, A., Deeds, D., Feinberg, A., Kos, G., et al., 2015. Mercury physicochemical and biogeochemical transformation in the atmosphere and at atmospheric interfaces: a review and future directions. Chem. Rev. 115, 3760-3802.

Aubail, A., Dietz, R., Rigét, F., Sonne, C., Wiig, , Caurant, F., 2012. Temporal trend of mercury in polar bears (Ursus maritimus) from Svalbard using teeth as a biomonitoring tissue. J. Environ. Monit. 14, 56-63.

Basu, N., Horvat, M., Evers, D.C., Zastenskaya, I., Weihe, P., Tempowski, J., 2018. A state-of-the-science review of mercury biomarkers in human populations worldwide between 2000 and 2018. Environ. Health Perspect. 126, https://doi.org/10. 1289/EHP3904.

Beal, S.A., Osterberg, E.C., Zdanowicz, C.M., Fisher, D.A., 2015. Ice core perspective on mercury pollution during the past 600 years. Environ. Sci. Technol. 49, 7641-7647.

Beattie, S.A., Armstrong, D., Chaulk, A., Comte, J., Gosselin, M., Wang, F., 2014. Total and methylated mercury in Arctic multiyear sea ice. Environ. Sci. Technol. 48, 5575-5582.

Bignert, A., Riget, F., Braune, B., Outridge, P., Wilson, S., 2004. Recent temporal trend monitoring of mercury in Arctic biota - how powerful are the exiting datasets. J. Environ. Monit. 6, 351-355.

Blukacz-Richards, E.A., Visha, A., Graham, M.L., McGoldrick, D.L., de Solla, S.R., Moore, D.J., et al., 2017. Mercury levels in herring gulls and fish: 42 years of spatio-temporal trends in the Great Lakes. Chemosphere 172, 476-487.

Bodaly, R.A., Jansen, W.A., Majewski, A.R., Fudge, R.J.P., Strange, N.E., Derksen, A.J., et al., 2007. Postimpoundment time course of increased mercury concentrations in fish in hydroelectric reservoirs of northern Manitoba, Canada. Arch. Environ. Contam. Toxicol. 53, 379-389.

Braaten, H.F.V., Åkerblom, S., de Wit, H.A., Skotte, G., Rask, M., Vuorenmaa, J., et al., 2017. Spatial and Temporal Trends of Mercury in Freshwater Fish in Fennoscandia (1965-2015). Norwegian Institute for Water Research, Oslo, Norway, 70 .

Braune, B.M., Gaston, A.J., Hobson, K.A., Gilchrist, H.G., Mallory, M.L., 2014 Changes in food web structure alter trends of mercury uptake at two seabird colonies in the Canadian Arctic. Environ. Sci. Technol. 48, 13246-13252.

Braune, B.M., Gaston, A.J., Mallory, M.L., 2016. Temporal trends of mercury in eggs of five sympatrically breeding seabird species in the Canadian Arctic. Environ. Pollut. 214, 124-131

Brigham, M.E., Sandheinrich, M.B., Gay, D.A., Maki, R.P., Krabbenhoft, D.P., Wiener, J.G., 2014. Lacustrine responses to decreasing wet mercury deposition rates - results from a case study in Northern Minnesota. Environ. Sci. Technol. 48, 6115-6123.

Burgess, N.M., Bond, A.L., Hebert, C.E., Neugebauer, E., Champoux, L., 2013. Mercury trends in herring gull (Larus argentatus) eggs from Atlantic Canada, 1972-2008: temporal change or dietary shift?. Environ. Pollut. 172, 216-222.

Chaulk, A., Stern, G.A., Armstrong, D., Barber, D., Wang, F., 2011. Mercury distribution and transport across the ocean-sea-ice-atmosphere interface in the Arctic Ocean. Environ. Sci. Technol. 45, 1866-1872.

Chen, C.Y., Driscoll, C.T., Eagles-Smith, C.A., Eckley, C.S., Gay, D.A., Hsu-Kim, H., et al., 2018. A critical time for mercury science to inform global policy. Environ. Sci. Technol. 52, 9556-9561. 
Chetelat, J., Amyot, M., 2008. Elevated methylmercury in high Arctic Daphnia and the role of productivity in controlling their distribution. Glob. Chang. Biol. 14, 1-13.

Clayden, M.G., Kidd, K.A., Wyn, B., Kirk, J.L., Muir, D.C.G., O'Driscoll, N.J., 2013. Mercury biomagnification through food webs is affected by physical and chemical characteristics of lakes. Environ. Sci. Technol. 47, 12047-12063.

Cole, A.S., Steffen, A., Pfaffhuber, K.A., Berg, T., Pilote, M., Poissant, L., et al., 2013 Ten-year trends of atmospheric mercury in the high Arctic compared to Canadian sub-Arctic and mid-latitude sites. Atmos. Chem. Phys. 13, 1535-1545.

Cole, A.S., Steffen, A., Eckley, C., Narayan, J., Pilote, M., Tordon, R., et al., 2014. A survey of mercury in air and precipitation across Canada: patterns and trends. Atmosphere 5, 635-668.

Cross, F.A., Evans, D.W., Barber, R.T., 2015. Decadal declines of mercury in adult bluefish (1972-2011) from the Mid-Atlantic Coast of the U.S.A. Environ. Sci. Technol. 49, 9064-9072.

Dietz, R., Riget, F., Boertmann, D., Sonne, C., Olsen, M.T., Fjeldsa, J., et al., 2006. Time trends of mercury in feathers of West Greenland birds of prey during 1851 2003. Environ. Sci. Technol. 40, 5911-5916.

Dietz, R., Outridge, P.M., Hobson, K.A., 2009. Anthropogenic contributions to mercury levels in present-day Arctic animals - a review. Sci. Total Environ. 407, $6120-6131$.

Drevnick, P.E., Cooke, C.A., Barraza, D., Blais, J.M., Coale, K.H., Cumming, B.F., et al., 2016. Spatiotemporal patterns of mercury accumulation in lake sediments of western North America. Sci. Total Environ. 568, 1157-1170.

Eagles-Smith, C.A., Ackerman, J.T., Willacker, J.J., Tate, M.T., Lutz, M.A., Fleck, J.A., et al., 2016. Spatial and temporal patterns of mercury concentrations in fresh water fish across the Western United States and Canada. Sci. Total Environ. 568, 1171-1184.

Eagles-Smith, C.A., Silbergeld, E.A., Basu, N., Bustamante, P., Diaz-Barriga, F., Hopkins, W.A., et al., 2018. Modulators of mercury risk to wildlife and humans in the context of rapid global change. Ambio 47, 170-197.

Evans, M., Muir, D., Brua, R.B., Keating, J., Wang, X., 2013. Mercury trends in predatory fish in Great Slave Lake: the influence of temperature and other climate drivers. Environ. Sci. Technol. 47, 12793-12801.

Faïn, X., Ferrari, C.P., Dommergue, A., Albert, M.R., Battle, M., Severinghaus, J., et al., 2009. Polar firn air reveals large-scale impact of anthropogenic mercury emissions during the 1970s. Proc. Natl. Acad. Sci. U. S. A. 106, 16114-16119.

Feng, X.B., Jiang, H.M., Qiu, G.L., Yan, H.Y., Li, G.H., Li, Z.G., 2009. Geochemical processes of mercury in Wujiangdu and Dongfeng reservoirs, Guizhou, China. Environ. Pollut. 157, 2970-2984.

Feng, X.B., Meng, B., Yan, H.Y., Fu, X.W., Yao, H., Shang, L.H., 2018. Biogeochemical Cycling of Mercury in Reservoir Systems in Wujiang River Basin. Science Press and Springer, Southwest China Beijing.

Fitzgerald, W.F., Lamborg, C.H., 2014. Geochemistry of mercury in the environment. In: Treatise on Geochemistry, 2nd ed. Elsevier.

Fu, X.W., Feng, X.B., 2015. Variations of atmospheric total gaseous mercury concentrations for the sampling campaigns of 2001/2002 and 2009/2010 and implication of changes in regional emissions of atmospheric mercury. Bull. Mineral. Petrol. Geochem. 34, 242-249.

Fu, X.W., Zhang, H., Yu, B., Wang, X., Lin, C.J., Feng, X.B., 2015. Observations of atmospheric mercury in China: a critical review. Atmos. Chem. Phys. 15, 9455-9476.

Fu, X.W., Zhu, W., Zhang, H., Sommar, J., Yu, B., Yang, X., et al., 2016. Depletion of atmospheric gaseous elemental mercury by plant uptake at Mt. Changbai, Northeast China. Atmos. Chem. Phys. 16, 12861-12873.

Gaden, A., Ferguson, S.H., Harwood, L., Melling, H., Stern, G.A., 2009. Mercury trends in ringed seals (Phoca hispida) from the western Canadian Arctic since 1973: associations with length of ice-free season. Environ. Sci. Technol. 43, 3646-3651.

Gandhi, N., Tang, R.W.K., Bhavsar, S.P., Arhonditsis, G.B., 2014. Fish mercury levels appear to be increasing lately: a report from 40 years of monitoring in the Province of Ontario, Canada. Environ. Sci. Technol. 48, 5404-5414.

Gustin, M.S., Evers, D.C., Bank, M.S., Hammerschmidt, C.R., Pierce, A., Basu, N., et al., 2016. Importance of integration and implementation of emerging and future mercury research into the Minamata Convention. Environ. Sci. Technol. 50, 2767-2770.

Hall, B.D., St. Louis, V.L., Rolfhus, K.R., Bodaly, R.A., B, K.G., Paterson, M.J., 2005 The impact of reservoir creation on the biogeochemical cycling of methyl and total mercury in boreal upland forests. Ecosystems 8, 248-266.

Heimbürger, L.-E., Sonke, J.E., Cossa, D., Point, D., Lagane, C., Laffont, L., et al., 2015. Shallow methylmercury production in the marginal sea ice zone of the central Arctic Ocean. Sci. Rep. 5, https://doi.org/10.1038/srep10318.

Horowitz, H.M., Jacob, D.J., Zhang, Y., Dibble, T.S., Slemr, F., Amos, H.M., et al., 2017. A new mechanism for atmospheric mercury redox chemistry: implications for the global mercury budget. Atmos. Chem. Phys. 17, 6353-6371.

Hsu-Kim, H., Eckley, C.S., Achá, D., Feng, X., Gilmour, C.C., Jonsson, S., et al., 2018. Challenges and opportunities for managing aquatic mercury pollution in altered landscapes. Ambio 47, 141-169.
Hutcheson, M.S., Smith, C.M., Rose, J., Batdorf, C., Pancorbo, O., West, C.R., et al., 2014. Temporal and spatial trends in freshwater fish tissue mercury concentrations associated with mercury emissions reductions. Environ. Sci. Technol. 48, 2193-2202.

Jardine, T.D., Kidd, K.A., O'Driscoll, N., 2013. Food web analysis reveals effects of $\mathrm{pH}$ on mercury bioaccumulation at multiple trophic levels in streams. Aquat. Toxicol. 132-133, 46-52.

Kang, S., Huang, J., Wang, F., Zhang, Q., Zhang, Y., Li, C., et al., 2016. Atmospheric mercury depositional chronology reconstructed from lake sediment and ice cores in the Himalayas and Tibetan Plateau. Environ. Sci. Technol. 50, 2859-2869.

Lepak, R.F., Yin, R., Krabbenhoft, D.P., Ogorek, J.M., DeWild, J.F., Holsen, T.M., et al., 2015. Use of stable isotope signatures to determine mercury sources in the Great Lakes. Environ. Sci. Technol. Lett. 2, 335-341.

Loseto, L.L., Stern, G.A., Macdonald, R.W., 2015. Distant drivers or local signals: where do mercury trends in western Arctic belugas originate? Sci. Total Environ. 509, 226-223.

Lucotte, M., Schetagne, R., Therien, N., Langlois, C., Tremblay, A., 1999. Mercury in the Biogeochemical Cycle: Natural Environments and Hydroelectric Reservoirs of Northern Québec (Canada). Springer, Berlin.

Mason, R.P., Sullivan, K.A., 1997. Mercury in Lake Michigan. Environ. Sci. Technol. 31, 942-947.

Mason, R.P., Abbott, M.L., Bodaly, R.A., Bullock Jr., O.R., Driscoll, C.T., Evers, D. et al., 2005. Monitoring the response to changing mercury deposition. Environ. Sci. Technol. 39, 14A-22A.

McKinney, M.A., Atwood, T.C., Pedro, S., Peacock, E., 2017. Ecological change drives a decline in mercury concentrations in Southern Beaufort Sea polar bears. Environ. Sci. Technol. 51, 7814-7822.

Meili, M., 1995. Liming effects on mercury concentrations in fish. In: Henrikson, L., Brodin, Y.W. (Eds.), Liming of Acidified Surface Waters-A Swedish Synthesis. Springer, Berlin, pp. 383-398.

Meng, B., Feng, X.B., Chen, C.X., Qiu, G.L., Sommar, J., Guo, Y.N., et al., 2010. Influence of eutrophication on the distribution of total mercury and methylmercury in hydroelectric reservoirs. J. Environ. Qual. 39, 1624-1635.

Meng, B., Feng, X.B., Qiu, G.L., Li, Z.G., Yao, H., Shang, L.H., et al., 2016. The impacts of organic matter on the distribution and methylation of mercury in a hydroelectric reservoir in Wujiang River, Southwest China. Environ. Toxicol. Chem. 35 191-199.

Obrist, D., Agnan, Y., Jiskra, M., Olson, C.L., Colegrove, D.P., Hueber, J., et al., 2017. Tundra uptake of atmospheric elemental mercury drives Arctic mercury pollution. Nature 547, 201-204.

Obrist, D., Kirk, J.L., Zhang, L., Sunderland, E.M., Jiskra, M., Selin, N.E., 2018. A review of global environmental mercury processes in response to human and natural perturbations: changes of emissions, climate, and land use. Ambio 47, 116-140.

Outridge, P., Mason, R., Wang, F., Guerrero, S., Heimburger-Boavida, L.-E., 2018. Updated global and oceanic mercury budgets for the United Nations Global Mercury Assessment 2018. Environ. Sci. Technol. 52, 11466-11477.

Pinkney, A.E., Driscoll, C.T., Evers, D.C., Hooper, M.J., Horan, J., Jones, J.W., et al., 2014. Interactive effects of climate change with nutrients, mercury, and ereshwater acidification on key taxa in the North Atlantic Landscape Conservation Cooperative Region. Integr. Environ. Assess. Manag. 11, 355-369.

Prestbo, E.M., Gay, D.A., 2009. Wet deposition of mercury in the US and Canada, 1996-2005: results and analysis of the NADP mercury deposition network (MDN). Atmos. Environ. 43, 4223-4233.

Rigét, F., Braune, B., Bignert, A., Wilson, S., Aars, J., Born, E., et al., 2011. Temporal trends of $\mathrm{Hg}$ in Arctic biota, an update. Sci. Total Environ. 409, 3520-3526.

Rigét, F., Dietz, R., Hobson, K.A., 2012. Temporal trends of mercury in Greenland ringed seal populations in a warming climate. J. Environ. Monit. 14, 3249-3256.

Risch, M., Kenski, D., 2018. Spatial patterns and temporal changes in atmospheric-mercury deposition for the Midwestern USA, 2001-2016. Atmosphere 9, 29. https://doi.org/10.3390/atmos9010029.

Saiz-Lopez, A., Sitkiewicz, S., Roca-Sanjuan, D., Oliva-Enrich, J., Davalos, J., Notario, R., et al., 2018. Photoreduction of gaseous oxidized mercury changes global atmospheric mercury speciation, transport and deposition. Nat. Commun. 9, 4796https://doi.org/10.1038/s41467-018-07075-3.

Sanei, H., Outridge, P.M., Goodarzi, F., Wang, F., Armstrong, D., Warren, K., et al., 2010. Wet deposition mercury fluxes in the Canadian sub-Arctic and southern Alberta, measured using an automated precipitation collector adapted to cold regions. Atmos. Environ. 44, 1672-1681.

Schroeder, W.H., Anlauf, K.G., Barrie, L.A., Lu, J.Y., Steffen, A., Schneeberger, D.R. et al., 1998. Arctic springtime depletion of mercury. Nature 394, 331-332.

Schuster, P.F., Schaefer, K.M., Aiken, G.R., Antweier, R.C., Dewild, J.F., Gryziec, J.D., et al., 2018. Permafrost stores a globally significant amount of mercury. Geophys. Res. Lett. 45, https://doi.org/10.1002/2017GL075571.

Slemr, F., Brunke, E.G., Ebinghaus, R., Kuss, J., 2011. Worldwide trend of atmospheric mercury since 1995. Atmos. Chem. Phys. 11, 4779-4787. 
St. Louis, V.L., JWM, Rudd, Kelly, C.A., Bodaly, R.A.D., Paterson, M.J., Beaty, K.G., et al., 2004. The rise and fall of mercury methylation in an experimental reservoir. Environ. Sci. Technol. 38, 1348-1358.

Stern, G.A., Macdonald, R.W., Outridge, P.M., Wilson, S., Chetelat, J., Cole, A., et al., 2012. How does climate change influence arctic mercury?. Sci. Total Environ. $414,22-42$.

Sunderland, E.M., Mason, R.P., 2007. Human impacts on open ocean mercury concentrations. Glob. Biogeochem. Cycles 21, https://doi.org/10.1029/2006GB002876.

Sunderland, E.M., Selin, N.E., 2013. Future trends in environmental mercury concentrations: implications for prevention strategies. Environ. Health 12.

Tang, R.W.K., Johnston, T.A., Gunn, J.M., Bhavsar, S.P., 2013. Temporal changes in mercury concentrations of large-bodied fishes in the boreal shield ecoregion of northern Ontario, Canada. Sci. Total Environ. 444, 409-416.

Tong, Y.D., Yin, X.F., Lin, H.M., Buduo, D., Wang, H.H., Deng, C.Y., et al., 2016. Recent decline of atmospheric mercury recorded by Androsace tapete on the Tibetan Plateau. Environ. Sci. Technol. 50, 13224-13231.

Wang, F., Zhang, J., 2013. Mercury contamination in aquatic ecosystems under a changing environment: implications for the Three Gorges Reservoir. Chin. Sci. Bull. 58, 141-149.

Wang, F., Macdonald, R.W., Stern, G.A., Outridge, P.M., 2010. When noise becomes the signal: chemical contamination of aquatic ecosystems under a changing climate. Mar. Pollut. Bull. 60, 1633-1635.

Wang, F., Pućko, M., Stern, G., 2017. Transport and transformation of contaminants in sea ice. In: Thomas, D.N. (Ed.), Sea Ice, 3rd ed. Wiley-Blackwell, Oxford, UK, pp. $472-491$

Weiss-Penzias, P.S., Gay, D.A., Brigham, M.E., Parsons, M.T., Gustin, M.S., ter Schure, S., 2016. Trends in mercury wet deposition and mercury air concentrations across the U.S. and Canada. Sci. Total Environ. 568, 546-556.
Wiener, J.G., Bodaly, R.A., Brown, S.S., Lucotte, M., Newman, M.C., Porcella, D.B., et al., 2007. In: Harris, R., Krabbenhoft, D.P., Mason, R., Murray, W., Reash, R. Saltman, T. (Eds.), Ecosystem Responses to Mercury Contamination. CRC Press, Boca Raton, pp. 87-122.

Willacker, J.J., Eagles-Smith, C.A., Lutz, M.A., Tate, M.T., Lepak, J.M., Ackerma, J.T., 2016. Reservoirs and water management influence fish mercury concentrations in the western United States and Canada. Sci. Total Environ. 568, 739-748.

Wu, Q.R., Wang, S.X., Li, G.L., Liang, S., Lin, C.J., Wang, Y.F., et al., 2016. Temporal trend and spatial distribution of speciated atmospheric mercury emissions in China during 1978-2014. Environ. Sci. Technol. 50, 13428-13435.

Yao, H., Feng, X.B., Guo, Y.N., Yan, H.Y., Fu, X.W., Li, Z.G., et al., 2011. Mercury and methylmercury concentrations in two newly constructed reservoirs in the $\mathrm{Wu}$ jiang River, Guizhou, China. Environ. Toxicol. Chem. 30, 530-537.

Zhang, Y., Jaeglé, L., 2013. Decreases in mercury wet deposition over the United States during 2004-2010: roles of domestic and global background emission reductions. Atmosphere 4, 113-131.

Zhang, Y., Jacob, D.J., Horowitz, H.M., Chen, L., Amos, H.M., Krabbenhoft, D.P., et al., 2016. Observed decrease in atmospheric mercury explained by global decline in atmospheric emissions. Proc. Natl. Acad. Sci. 113, 201516312.

Zheng, J., 2015. Archives of total mercury reconstructed with ice and snow from Greenland and the Canadian High Arctic. Sci. Total Environ. 509-510, 133-144.

Zhou, C., Cohen, M.D., Crimmins, B.A., Zhou, H., Johnson, T.A., Hopke, P.K., et al., 2017. Mercury temporal trends in top predator fish of the Laurentian Great Lakes from 2004 to 2015: are concentrations still decreasing?. Environ. Sci. Technol. 51, 7386-7394. 